\title{
'Are You There God?': Secularization of Religious Narratives in Contemporary Cinema
}

\author{
by \\ Mary O’Shea
}

A thesis submitted to the Faculty of Graduate and Postdoctoral Affairs in partial fulfillment of the requirements for the degree of

Master of Arts

in

Film Studies

Carleton University

Ottawa, Ontario

(C) 2013, Mary O’Shea 


\begin{abstract}
The budding field of religion and film has almost exclusively consisted of works by religious studies scholars. The objective of this thesis is to approach religion and film from a film studies standpoint, with a focus on narrational, stylistic, and genre analysis. The films explored, Silent Light (Carlos Reygadas, Mexico, 2007), Requiem (HansChristian Schmid, Germany, 2006), and Take Shelter (Jeff Nichols, USA, 2011), are not a part of the popular Western cinema that dominates religion and film discourses. These independent works about resurrection (Silent Light), possession (Requiem), and apocalypse (Take Shelter) secularize the religious element of their respective narratives, and as a result, there is room for doubt, hesitation, and a variety of interpretations. The ambiguous sensibility of these films is crucial to this thesis, which aims to complicate the notion of the "religious film."
\end{abstract}




\section{ACKNOWLEDGEMENTS}

This thesis would not exist without the guidance and insight of my supervisor, Dr. Malini Guha. Thank you for two years of thoughtful conversations, and your steadfast encouragement throughout the evolution of this project.

I am grateful to have had the opportunity to learn from the exceptional Film Studies faculty at Carleton, particularly Dr. Charles O’Brien, Dr. Erika Balsom, Dr. Marc Furstenau, Dr. Zuzana Pick, and Dr. Aboubakar Sanogo. A special thanks to the always helpful Diane Berezowski, Jack Coghill, Laurie Jaeger, and Barbara Shannon.

Thank you to my fellow students, including those who graduated in 2012 yet continue to offer me advice and support, especially Jennifer Dobbs, Patrick Mullen, Renuka Bauri, Kate Allen, Keltie Duncan, and Jordan Gowanlock. Thank you to my officemates Kevin Chabot and Amy Jane Vosper, especially for being by my side during my first ever viewing of The Exorcist.

Thank you to Dr. David Hawkin, Dr. David Bell, Dr. Michelle Rebidoux, Dr. Jennifer Porter, and the rest of the Religious Studies Department at Memorial University, for igniting my interest in religious studies, and thus critically impacting this thesis project.

I am especially grateful to my family and friends for their unending patience and encouragement. Thank you in particular to my parents, for teaching me the value of lifelong education. 


\section{TABLE OF CONTENTS}

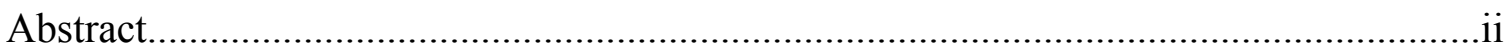

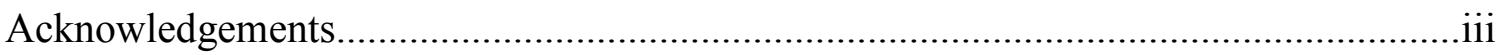

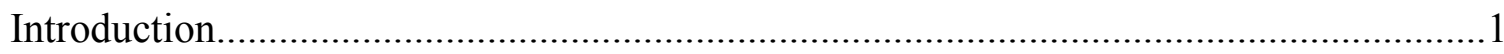

Chapter One

Witnessing the Miraculous: Transcendental Style in Silent Light ..............................12

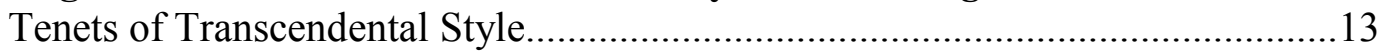

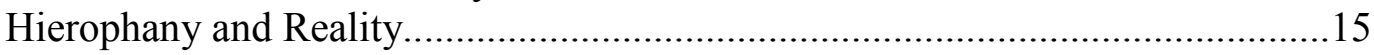

Silent Light's Transcendental Style.................................................................17

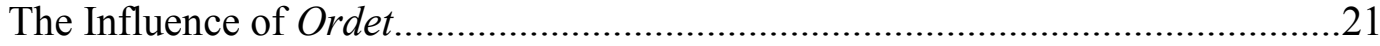

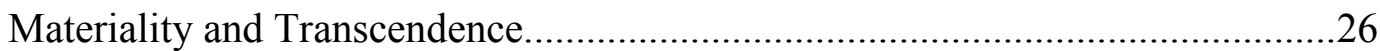

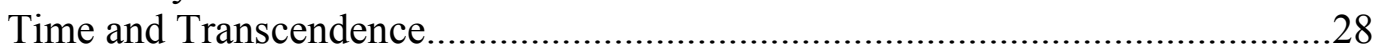

Transcendental Style and Art Cinema.................................................................30

Chapter Two

Inner Demons: The Exorcism Film Genre and the Case of Requiem ..........................35

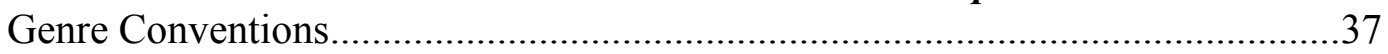

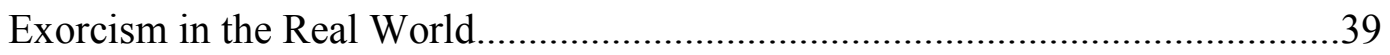

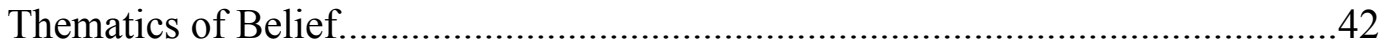

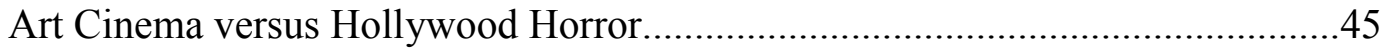

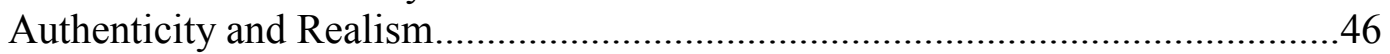

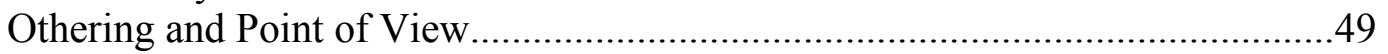

Horror Cinema and "Divine Madness"..............................................................51

Possession Syndrome .......................................................................................5

Chapter Three

"There's a Storm Coming": Apocalypticism and the Fantastic in Take Shelter........59

The Pervasiveness of Apocalyptic Film..............................................................61

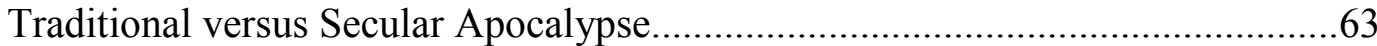

Apocalyptic Dread........................................................................................65

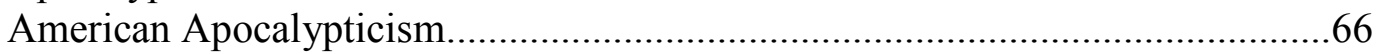

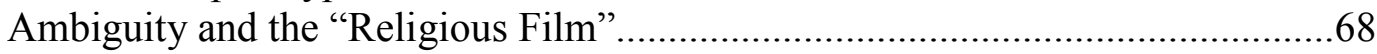

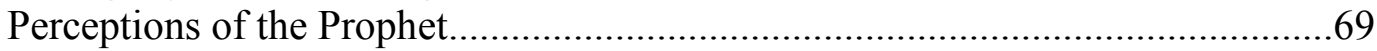

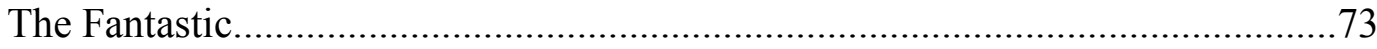

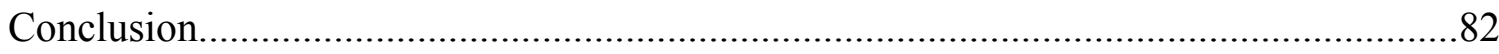

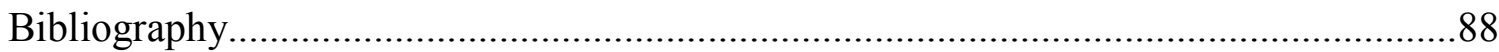




\section{INTRODUCTION}

Some things have to be believed to be seen. -Ralph Hodgson

Various facets of religion have been implicitly and explicitly explored in countless films made since the earliest days of the medium. An often-cited quote by film theorist André Bazin declares, "The cinema has always been interested in God."1 The term "religious film" is difficult to define, but films with palpable religious content, which engage with issues surrounding faith and the spiritual, are those most easily classified as religious films. For the specific purposes of this thesis, "religious film" refers to a film that in some way affirms religious belief. Such films include Cecil B. DeMille's The Ten Commandments (1956), and even Steven Spielberg's Close Encounters of the Third Kind (1977). While the former is a well-known Christian story, the latter is a religious allegory, in which the revelation of an extraterrestrial spaceship is representative of a biblical revelation. ${ }^{2}$ A religious film may affirm belief in an explicit way, such as in The Ten Commandments, or may feature an allegorically explicit affirmation, as in Close Encounters of the Third Kind. These are examples of a trend of scholarly work on popular cinema that had tended to dominate recent work on religion and film.

Most of the texts written about religion and film have been published in the last 15 years. The authors of these texts are almost exclusively scholars of religious studies or theology. ${ }^{3}$ The most common approaches toward the subject include the discussion of biblical allusions, Christ figures, religious symbols, and themes of faith, rebirth, and redemption. Most of the films discussed are popular, Western films, or films by renowned directors; in essence, films that are already familiar to most audiences. For 
example, the back cover of The Routledge Companion to Religion and Film proclaims that the collection includes "films as diverse as" The Passion of the Christ (Mel Gibson, 2004), The Matrix (Andy Wachowski and Lana Wachowski, 1999), Star Wars (George Lucas, 1977), and Groundhog Day (Harold Ramis, 1993). ${ }^{4}$

Many religion and film texts concentrate on popular American film, such as Image \& Likeness: Religious Visions in American Film Classics (1992) edited by John R. May, and Screening the Sacred: Religion, Myth, and Ideology in Popular American Film (1995) edited by Joel W. Martin and Conrad E. Ostwalt Jr. In Seeing and Believing: Religion and Values in the Movies (1996), Margaret R. Miles argues that popular film "both reflects a popular consensus that traditional religion is deeply untrustworthy and reinforces our public rejection of religion." ${ }^{, 5}$ Miles states that she chooses to work on popular film because "it provides an index of the anxieties and longings of a large audience." ${ }^{\prime 6}$ Other texts focus on elements of Christianity, particularly how scripture is adapted in film, such as Scripture on the Silver Screen (2003) by Adele Reinhartz, and Screening Scripture: Intertextual Connections Between Scripture and Film (2002) edited by George Aichele and Richard Walsh.

Several of the texts discuss the Christian beliefs of their contributors. In Faith, Film and Philosophy: Big Ideas on the Big Screen (2007), R. Douglas Geivett and James S. Spiegel ask, "what can films teach us about our beliefs, our values and the way that we go about developing our worldviews?"7 Geivett and Spiegel state that their subject matter is philosophical, and comment that their contributors share a Christian perspective. In the introduction to Explorations in Theology and Film: Movies and Meaning (1997), Clive Marsh and Gaye Ortiz note that most of the essayists of their collection are writing from a 
Christian viewpoint, and that the central question of their text is how Christian theology converses with film. ${ }^{8}$

There are a few texts that have approached the subject of religion and film through notably innovative methodologies. Film as Religion: Myths, Morals, and Rituals (2003) by John Lyden develops an analogous relationship between religion and film. Lyden contends that there is no absolute distinction between religion and other aspects of culture, such as film. He is critical of previous approaches to religion and film that he claims can be categorized as "ideological" or "theological". ${ }^{9}$ The focus of Lyden's work is on how films function for audiences, rather than the content of films.

Lyden is also the editor of The Routledge Companion to Religion and Film (2009), and of the online Journal of Religion \& Film. On its website, hosted by the University of Nebraska Omaha, the objectives of the journal are as follows:

We encourage multiple approaches to the study of religion and film, including (but not limited to) the analysis of how religious traditions are portrayed in films; exploration of the religious concepts that may be found or utilized in the interpretation of films; study of how the religious ideals and background of the filmmakers may have influenced them; and analysis of how films themselves may operate "religiously" for viewers. ${ }^{10}$

Each of the approaches mentioned in this statement reflect dominant trends within religion and film scholarship. Notably, many of the religion and theology scholars mentioned above have contributed pieces to the Journal of Religion \& Film, and/or serve on the editorial board, including Clive Marsh, and Margaret Miles.

Another notable scholar in the field (and contributor to the Journal of Religion \& Film) is S. Brent Plate, who has published works including Religion and Film: Cinema and the Re-Creation of the World (2003), and co-edited the Religion and Film Reader (2007) with Jolyon Mitchell. Plate's work, unlike most, considers films from around the 
world, and religions beyond Christianity and monotheism. The objective of Plate and Mitchell's reader is to showcase the historical and global dimensions of the relationship between religion and film. Plate and Mitchell claim that religion "is a lens through which the world can be described, re-described and then comprehended in a deeper manner" and that film has the potential to "mirror or reveal the world". ${ }^{11}$ The Religion and Film Reader is divided into five parts, which explore the history of religion in film, early film theory, global perspectives, theological approaches to film analysis, and the relationship between religion and film. The essays and excerpts included come from an array of sources, some film theorists, some religion scholars, and some filmmakers. Plate and Mitchell's collection is a useful survey of approaches taken to the study of religion and film.

One of the most compelling texts about religion and film is The Hidden God: Film and Faith, a collection of essays edited by Mary Lea Bandy and Antonio Monda. Unlike most of the anthologies on the subject, it is not based in religious studies or theology. Bandy and Monda are curators at the Museum of Modern Art in New York. The essayists are not "experts" on religion, but rather are film historians, critics, scholars, and filmmakers, and include Andrew Sarris and Martin Scorsese. Most of the contributors are American, but the films they discuss represent a wide range of countries, genres and decades. The book's publication in 2003 coincided with a film series in the MoMA Film at the Gramercy Theatre program. The introduction to the anthology explains the idea of a "hidden" god as the absence or hidden presence of a deity. Bandy and Monda argue that this concept is "embedded in the Christian heritage through the divide between the unrepresentable God of Israel ('Thou shalt not make thee any graven 
image') who spoke out of the whirlwind and the incarnated and therefore revealed God of the New Testament."12 They claim that the notion of a "hidden" god has gained a particular resonance in the language of cinema.

Despite these important works, there remains a significant limitation in the field of religion and film, namely, a lack of scholarship rooted in film studies. The way religion is presented in film, and more broadly, the relationship between religion and film has gained tremendous popularity in theology and religious studies in recent years, yet little has been written by film scholars on the topic. This is not to say that there is no history of a discussion of religion in film studies. ${ }^{13}$ The works of André Bazin and Paul Schrader are perhaps the most prominent examples of religion and film discourses by film scholars. Bazin, well known for his Catholicism, criticized the semiotic approach to film theory, and claimed that cinema has the ability to reach a spiritual reality. ${ }^{14}$ Two film scholars influenced by Bazin, Henri Agel and Amédée Ayfre, published works in the 1950s and early 1960s advocating a phenomenological approach to cinema as a way of exploring how the transcendent can be conveyed through film. Agel and Ayfre's work has recently been revived by film scholar Andrew Quicke. According to Quicke, Agel and Ayfre "search for a spiritual reality beyond purely semiotic and materialistic theories represented in cinema criticism today." ${ }^{15}$ Quicke explains that the work of Agel and Ayfre is still relatively unknown, at least in North America, because it has yet to be translated into English. However, Agel and Ayfre's work had a significant impact on Paul Schrader's 1972 text, Transcendental Style in Film. ${ }^{16}$ Schrader's work continues the exploration of cinematic expressions of the transcendent. Transcendental Style in Film puts forth a definition for a transcendental film style, which Schrader claims is universal, 
and exemplified by the films of Yasujiro Ozu, Robert Bresson, and Carl Theodor Dreyer. ${ }^{17}$ As the works of Schrader, Agel, Ayfre, and Quicke indicate, there is an evident, albeit sporadic tradition of discussing religion in film. However, the formalization of what might be referred to as the subfield of "religion and film," as a recognizable category of inquiry, is, as previously stated, a recent development.

In Explorations in Theology and Film, Marsh and Ortiz claim that, "In film and media studies, though screen literacy may often be very high indeed, attentiveness to religious symbolism and theological tradition - both implicit and explicit in so many Western films - may not."18 They argue that the influence of Christian theology on Western art is often overlooked. This thesis project engages in an inverse critique of Marsh and Ortiz's assertions. Among the texts published about religion and film, there is very little discussion of film as an art form, or formal film analysis. The purpose of this thesis is to approach the subject of religion and film from a film studies perspective, with a focus on narrational, stylistic, and genre analysis. The following chapters will investigate three contemporary films: Silent Light (Carlos Reygadas, Mexico, 2007), Requiem (Hans-Christian Schmid, Germany, 2006), and Take Shelter (Jeff Nichols, USA, 2011). As previously mentioned, most of the films considered in religion and film scholarship are Hollywood films, or at least popular Western films by well-known filmmakers. Silent Light, Requiem, and Take Shelter were purposely selected because they fall outside the realm of popular Western cinema, and are not included in religion and film scholarship. ${ }^{19}$ Requiem is a German film, Silent Light is a Mexican production, and although Take Shelter is an American film, it is an independent production written and directed by a relatively unknown filmmaker. Each of these films has been well 
received by film critics and international film festivals, but they are not well known by “average" filmgoers.

As Silent Light, Requiem, and Take Shelter are not popular films, they do not employ typical genre and narrative conventions. Significantly, these films about resurrection, possession, and apocalypse are not discernibly religious films, or films about religion. There is an ambiguity to each of the films, which emerges through narrational and formal means. This ambiguity lies at the crux of this thesis. Most of the films discussed in religion and film scholarship affirm religious belief. Silent Light, Requiem, and Take Shelter, however, present religious content in a secularized way, which leaves room for doubt, hesitation, and a variety of interpretations. Secularization, for the purposes of this thesis, can be understood as the absence of God, or divine agency, which thwarts the affirmation of belief that is found in religious films. This conception of secularization is informed by Bandy and Monda's The Hidden God, as well as Conrad Ostwalt's definition of secular apocalyptic narratives, which will be discussed in Chapter Three.

Chapter One will examine Silent Light, through Schrader's theory of transcendental style, and in relation to Carl Dreyer's 1955 film Ordet, which Schrader discusses in Transcendental Style in Film, and which is a direct influence on the ending and style of Silent Light. Set in a Mennonite community in Chihuahua, Mexico, Silent Light centres on Johan (Cornelio Wall), a middle-aged farmer, husband, and father of six children, who has been having an affair with a local woman named Marianne (Maria Pankratz). Johan is honest about the relationship with his wife, Esther (Miriam Toews), and although he feels bad about hurting her, he is unable to overcome his feelings for 
Marianne. The dilemma of the protagonist has been the focus of countless other films. However, Silent Light is remarkable for the way it conveys the story. The film exemplifies the transcendental style outlined by Schrader, particularly in its depiction of the everyday. This changes when Esther unexpectedly dies, and is subsequently brought back to life at her wake by Marianne. The resurrection scene is a recreation of the final scene in Ordet. The major difference is that the resurrection in Ordet has a religious significance for the characters, who perceive it as an act of God, while in Silent Light, there is no suggestion that God is responsible for the event.

In Chapter Two, Requiem will be examined in relation to other films about exorcism and possession, such as The Exorcist (William Friedkin, 1973), which leave no room for a natural explanation of events. Requiem complicates the exorcism film genre, as it does not fit the conventions of a horror film. In Requiem, a young woman who has been diagnosed with epilepsy leaves her hometown to go to university. She hears voices and experiences a loss of control of her body, believing that she is possessed by demons. Michaela (Sandra Hüller) comes from a very religious family, and seeks help from her parish priest. The priest first tells her to see a doctor. However, as her experiences continue, he brings a young priest, who has experience with exorcism, to see her. Michaela's friends and family are divided in their perception of what is happening to her. Unlike most films about exorcism and possession, there is no "evidence" of the supernatural in Requiem. The film ends without resolving Michaela's condition, but the postscript states that she died of exhaustion after multiple exorcisms. The "true story" that the film is based on also inspired The Exorcism of Emily Rose (Scott Derrickson, 2005). The American film focuses on the trial of a priest who is charged with murder 
when a girl dies after he performed an exorcism on her. While The Exorcism of Emily Rose and Requiem have the same basic premise, they depict the events in strikingly different ways. This has significant implications for how the religious content of each film is read.

Chapter Three will examine Take Shelter in the context of the prevalent apocalyptic film genre, as well as narratives with prophetic protagonists, namely, Close Encounters of the Third Kind. The focus of the chapter will be the hesitation between a religious and non-religious explanation for the events in the film, and how director Jeff Nichols maintains this hesitation until the end. The narrative of Take Shelter centres on a working-class man in his thirties who experiences apocalyptic visions. Aware of his family's history of schizophrenia, he seeks psychological help to try to understand and deal with the visions. However, he is also compelled to act on them, and begins building a storm shelter in his backyard. The film is not explicitly religious, and while Curtis (Michael Shannon) seeks a natural explanation for his visions, the images and nature of his visions make him wonder if a supernatural event is really coming. The film presents Curtis' experiences in a way that maintains the ambiguity between the natural and supernatural, or as Tzvetan Todorov posits in The Fantastic: A Structural Approach to a Literary Genre (1977), the uncanny and the marvelous. Notably, the ending of the film does not provide a clear conclusion. The ambiguity of the narrative remains for the spectator, while Curtis seems to reach a degree of resolution.

As previously stated, Silent Light, Take Shelter, and Requiem fall outside the canon of most religion and film texts. They are not popular films, and they defy the conventions of more traditional religious films. The ending of each of these films 
withholds a sense of conclusion and explanation. This ambiguity allows for multiple interpretations of the films, and complicates labeling any of them "religious films". The focus of study for each of these films is the unusual ways in which they engage with religion, and the styles of filmmaking employed which create an ambiguity concerning the possibility of the supernatural. Effectively, this ambiguity stems from the secularization of these religious stories about a miraculous resurrection, demonic possession, and apocalyptic prophecy. These films withhold a straightforward religious or supernatural explanation and thus maintain an indeterminate and ambiguous position towards the religious.

Bandy and Monda's concept of a hidden god, like Schrader's notion of the transcendent, is applicable to films which may not be explicitly religious, but which nevertheless suggest the presence of a spiritual element. Essentially, both works explore how religion may be found in unexpected ways, in unexpected films. In the following chapters, this thesis will investigate films where religion is not found in the places one might expect.

\section{Notes}

${ }^{1}$ Sheila J. Nayar, The Sacred and the Cinema: Reconfiguring the "Genuinely" Religious Film, (New York: Continuum, 2012), 36.

${ }^{2}$ Antonio Monda, "Close Encounters of the Third Kind," in The Hidden God: Film and Faith, ed. Mary Lea Bandy and Antonio Monda, (New York: The Museum of Modern Art, 2003), 151.

${ }^{3}$ Those investigated for this thesis, many of whom are directly referenced within, include: Margaret Miles, Clive W. Marsh, Joel Martin, Conrad Ostwalt Jr, Gaye Ortiz, S. Brent Plate, John Lyden, Richard G. Walsh, George Aichele, Christopher Deacy, Adele Reinhartz, John R. May, R. Douglas Geivett, Robert K. Johnston, Michael Bird. 
${ }^{4}$ Routledge, Fourth Cover of The Routledge Companion to Religion and Film, ed. John Lyden, (New York: Routledge, 2009).

${ }^{5}$ Margaret R. Miles, Seeing and Believing: Religion and Values in the Movies, (Boston: Beacon, 1996), IX.

${ }^{6}$ Ibid, 10.

${ }^{7}$ R. Douglas Geivett and James S. Spiegel, Faith, Film and Philosophy: Big Ideas on the Big Screen, (Downers Grove, IL: IVP Academic, 2007), 10.

${ }^{8}$ Clive Marsh and Gaye Ortiz, eds., Explorations in Theology and Film: Movies and Meaning, (Oxford: Blackwell, 1997), 2.

${ }^{9}$ John C. Lyden, Film as Religion: Myths, Morals, and Rituals, (New York: New York UP, 2003), 3.

10 "About this Journal," Journal of Religion \& Film, hosted by the University of Nebraska Omaha, http://digitalcommons.unomaha.edu/jrf/about.html.

${ }^{11}$ Jolyon Mitchell and S. Brent Plate, eds., The Religion and Film Reader, (New York:

Routledge, 2007), 46.

${ }^{12}$ Mary Lea Bandy and Antonia Monda, eds., The Hidden God: Film and Faith, (New York:

Museum of Modern Art, 2003), 10.

${ }^{13}$ Scholarship on Indian cinema, particularly the popular film tradition of Bollywood, does often include a discussion of religion. For more on this area, see the works of Rachel Dwyer, including Filming the Gods: Religion and Indian Cinema.

${ }^{14}$ Andrew Quicke, "Phenomenology in Film: An Examination of a Religious Approach to Film Theory by Henri Agel and Amédée Ayfre," Journal of Media \& Religion 4, no.4 (2005): 239.

${ }^{15}$ Ibid, 236.

${ }^{16}$ Ibid.

${ }^{17}$ Paul Schrader, Transcendental Style in Film: Ozu, Bresson, Dreyer, (Berkeley: University of California Press, 1972), 3.

${ }^{18}$ Marsh and Ortiz, Explorations in Theology and Film, 3.

${ }^{19}$ The singular exception is a review of Take Shelter in the Journal of Religion \& Film by Dereck Daschke. Daschke's essay is referenced in Chapter Three. 


\section{ChaPTer ONe}

Witnessing the Miraculous: Transcendental Style in Silent Light

The highest art is always the most religious; and the greatest artist is always a devout man. -John Stuart Blackie

Although religion and film scholarship is attentive to trends in contemporary film, it has largely overlooked recent art cinema in favour of popular cinema. At the same time, film scholars who analyze the formal elements of art films seldom do so with consideration of a religious framework. The purpose of this chapter is to examine the intersection of contemporary art cinema and religion, through the analysis of Carlos Reygadas' film, Silent Light (2007).

In his text, Transcendental Style in Film, Paul Schrader posits that there is a universal film style that can express the transcendent. Originally published in 1972, Transcendental Style in Film remains a noteworthy and rare example of a religion and film text written by a film studies scholar. Schrader's text offers a way of thinking about religion and film through the analysis of film style, and for this reason, it will be the foundation for contemplating how Silent Light may or may not be considered a religious film. Additionally, Silent Light will be examined in relation to Carl Dreyer's 1955 film, Ordet, which Schrader uses to illustrate the components of transcendental style, and which inspires the pivotal resurrection sequence in Silent Light.

Given that Schrader considers Ordet the best example of transcendental style among Dreyer's films, it may seem appropriate to claim that Silent Light also fits Schrader's definition of a transcendental film. However, there are significant differences between the two films, in terms of the depiction of character, conflict, and aesthetics. What Silent Light shares with Ordet is an unexpected resurrection at the end of the film, 
and a peculiar depiction of time. Yet Silent Light critically diverges from Ordet in that it secularizes the resurrection, and thus alters how the film conveys transcendence.

\section{Tenets of Transcendental Style}

In Transcendental Style in Film, Schrader writes, "In recent years film has developed a transcendental style, a style which has been used by various artists in diverse cultures to express the Holy." "Schrader claims that transcendental style is not inherently religious, but represents one way of approaching the transcendent, and is a result of two universal contingencies: "the desire to express the Transcendent in art and the nature of the film medium. ${ }^{2} \mathrm{He}$ asserts that transcendental style is a determinable film style, which uses "precise temporal means - camera angles, dialogue, editing - for predetermined transcendental ends." ${ }^{3}$

Schrader's definition of the transcendent, and transcendental style, is lengthy and multifaceted. Firstly, he describes the transcendent as "beyond normal sense experience, and that which it transcends is, by definition, the immanent." ${ }^{\text {4 }}$ Schrader then offers a trifold definition of transcendental: "the Transcendent, the Holy, or Ideal itself"; "the transcendental, human acts or artifacts which express something of the Transcendent"; and "the human religious experience" of transcendence, which may be motivated by "deep psychological need or neurosis" or by an external force. ${ }^{5}$ The second part of this definition (human acts or artifacts which express something of the Transcendent) is the relevant aspect in terms of the film style Schrader describes. Moreover, he states that a variety of sacred art works can be considered transcendental, including works that inform the spectator about the transcendent; works that express the transcendent in human reflection; and works that relate the human experience of transcendence. ${ }^{6}$ His focus in 
Transcendental Style in Film is on the second type of sacred art works, transcendental art that expresses the transcendent "in the human mirror". ${ }^{7}$ Schrader suggests that humanmade works, such as films, can express the transcendent though not directly reveal it.

Schrader's definition of "style" draws upon art historian Heinrich Wölfflin's understanding of a "general representative form," and "the expression of similar ideas in similar forms by divergent cultures". ${ }^{8}$ He explains that Wölfflin's definition is concerned with the universal and is therefore ideal for describing a style "which seeks to express the Wholly Other through divergent cultures and personalities." ${ }^{\prime 9}$ Schrader names his approach to transcendental style the Eliade-Wölfflin method, combining religious historian Mircea Eliade's notion of hierophanies with Wölfflin's term for common film forms and techniques. Schrader acknowledges that his method is based on the premise that hierophanies exist, which he states are expressions of the transcendent in society. ${ }^{10}$ The universality of transcendental style is emphasized throughout the text, and Schrader's comparative analysis of Ozu and Bresson, in particular, aims to prove that filmmakers from completely different backgrounds can employ the same method for conveying the transcendent.

There are several assumptions and omissions in Schrader's work. He claims that films that inform the viewer about the transcendent "by their very definition must come directly from the Transcendent itself since no man can know about the Holy."11 Schrader's statements presume the existence of $a$ transcendent. His capitalization of the words "Transcendent," and "Holy" further indicate his belief in the existence of a holy being. He leaves no room for a consideration of atheism, or how individual viewers may 
respond differently to the same film. These aspects of Schrader's writing make it seem dated.

\section{Hierophany and Reality}

While Schrader's work is significant because so few film scholars write about religion, his theory of transcendental style is not incompatible with some works by other religion and film scholars, such as Michael Bird's frequently-cited essay, "Film as Hierophany” (1982). Bird, like Schrader, employs Mircea Eliade's authoritative definition of hierophany, "to designate the act of manifestation of the sacred." ${ }^{12}$ Bird states that a hierophany is a "disclosure of the transcendent or sacred precisely through the material of reality," and claims film is a "locus" of a hierophanous manifestation. ${ }^{13}$

A common aspect of both Schrader and Bird's work is an emphasis on the role of realism in expressing transcendence. One of the most significant claims Bird makes is that a realist style is most apt for expressing the transcendent.

If film is understood to possess a continuity with the world it represents, then in order for cinema to have a means by which it can open us to the dimension of the sacred, this means would have to be directed to the discernment of the holy within the real, rather than leading away from the real as in the case of art that abolishes reality. ${ }^{14}$

Bird, like Schrader, presupposes the existence of the sacred, which he believes can be explored by a filmic style. Whereas Schrader uses the term "transcendental style," Bird describes a "cinematic theology" ${ }^{15}$ Bird contends that in religious films, the recording of reality "does not exhaust reality but evokes in the viewer the sense of its ineffable mystery." 16

However, Bird differs from Schrader on his view of the beauty of images. He writes, "a realism which is poetic (sensitive to beauty) is simultaneously a realism which 
is spiritual (sensitive to meaning)" ${ }^{17}$ It is unclear if Bird is only referring to religious films here. It is difficult to understand how or why any "poetic" realism in film must be spiritual. Is it not possible for beauty to be secular? Film critic Leo Bankersen makes a similar comment about Schrader's transcendental style: "Some would like to compare this to a religious experience - the less religiously inclined might call it poetic." 18

Despite its limitations, Transcendental Style in Film remains a useful text for a discussion of religion and film, and is applicable to contemporary films such as Silent Light. Furthermore, Schrader's approach is conducive to formal film analysis, which is not often a component of discourses on religion and film. Schrader outlines three key attributes of transcendental style: the everyday, disparity, and stasis, which are the primary means of situating Silent Light as a transcendental film. The everyday is "a meticulous representation of the dull, banal commonplaces of everyday living." 19 Schrader states that it is cold and expressionless with the purpose of preparing reality "for the intrusion of the Transcendent." ${ }^{20}$ The everyday gives way to disparity, "an actual or potential disunity between man and his environment which culminates in a decisive action. ${ }^{21}$ Disparity creates suspicion of the emotionless everyday, and suggests to the spectator that there is something else beneath "the dull surface of everyday reality." 22 Schrader's notion of disparity is informed by film theorist Amédée Ayfre, who claims that disparity is caused by the "insertion of 'human density' into the cold context of the everyday." 23 The final step Schrader describes is stasis, "a frozen view of life which does not resolve the disparity but transcends it." ${ }^{24}$ 


\section{Silent Light's Transcendental Style}

Each of the three properties of transcendental style can be identified in Silent Light, the third feature film by Mexican filmmaker Carlos Reygadas. Influenced by directors such as Andrei Tarkovsky and Michelangelo Antonioni, Reygadas' film style is

known for its realism and subtlety. ${ }^{25}$ José Castillo writes that Reygadas' films are distinctive from the films associated with New Mexican Cinema, which fit most Hollywood conventions. ${ }^{26}$

The protagonist of Silent Light is Johan (Cornelio Wall), a family man and father living in a Mennonite community in Mexico. Despite his devotion to his six children, and his wife, Esther (Miriam Toews), Johan has been having an affair with another Mennonite woman named Marianne (Maria Pankratz). Johan's struggle to reconcile his love for Marianne with his familial duty and his religious convictions is the focus of most of the film. His internal conflict is evident from the beginning of the film, when Esther and the children leave the house, and Johan sits silently at the kitchen table and then begins crying, with evident despair.

The majority of the film epitomizes Schrader's concept of the everyday. The realist features of Silent Light are, aside from the miraculous ending, the most remarkable aspect of the film. The entire cast is comprised of non-professional actors who were recruited by Reygadas from Mennonite communities in Mexico, Canada, and Germany. ${ }^{27}$ The Mennonite cast adds to the authenticity of the film, as does the dialogue, which is in Plautdietsch, a low Germanic dialect spoken in many Mennonite communities. ${ }^{28}$ The dialogue in the film is mostly monotone, delivered without inflection, and the style of acting generally is undramatic. In an interview, Reygadas explains that he sometimes ties 
strings to his actors' legs and then pulls on one of the strings when he wants an actor to move or speak. ${ }^{29}$ This technique allows him to control the timing of speech and movement and stops the actors from thinking about it. However, there is also a sense in Silent Light that the camera is capturing undirected moments that are documentary-like. In one scene, Johan and Esther take their children to a bathing pool. The first several minutes only show the children swimming and playing. They seem very much aware of the camera, and occasionally glance at it. The position of the camera in some shots suggests the point of view of one of the children or their parents, while at other moments it remains fixed, simply capturing whatever happens in front of it, and does not follow the action. Reygadas states: “My film is 'fiction,' though I used 'real' materials. Silent Light could be seen as a better documentary on Mennonites in Mexico than one produced by National Geographic."30

Silent Light was shot mainly outside, and on location in Chihuahua. There is no musical score, and all sound is diegetic. The use of sound in the film is significant. The opening and closing shots show only the sky, but feature the sounds of cicadas, birds, and a cacophony of farm animals. The sounds of the farm are heard throughout the film, even though their source is almost never shown. The combination of sound and image helps to convey the natural, pastoral aspect of the film, and is a feature Silent Light shares with Ordet.

Another key element that helps express a sense of the everyday in Silent Light is the use of the long take, which gives rise to a sense of duration. Additionally, there is little or no camera movement in most scenes. The slow paced editing of the film matches the unhurried movement of the characters. In particular, the scenes where the long take is 
combined with a static long shot contribute to an uneventful sense of everyday life in Chihuahua's Mennonite community. Early in the film, Johan visits his friend Zacharias (Jacobo Klassen) at his garage to pick up a piece of farming equipment. A static, extreme long shot shows an empty space of dirt and grass in front of a cornfield, with a cloudfilled blue sky encompassing the top half of the frame, and Johan's pickup truck at the far right. Johan, Zacharias, and another worker enter the frame from the left and walk across to the truck, where Zacharias and the other man toss the crank they have been carrying into the truck bed while Johan watches. All three men remain still, leaning against the truck for a moment before the shot changes. Sequences such as this do nothing to advance the plot or develop the characters. Rather, they emphasize the banal aspect of daily life, which is the essence of Schrader's concept of the everyday.

The everyday of Silent Light disintegrates late in the film, when Johan confesses to Esther that he has not been able to stop seeing Marianne. Johan and Esther are driving on the highway, and Esther asks Johan to pull the truck over so she can get out. It is pouring rain as Esther runs to a tree near the side of the road, and cries until she collapses. Johan discovers her lifeless body and brings her to a doctor who explains that she has died of a heart attack. The doctor's suggested causes of the attack, including obesity and old age, clearly do not apply to Esther. It is her grief over her husband's continuing affair that causes her to literally die of a broken heart. Esther's outpouring of emotion in the moments before her death is a shift in the tone of the film up until this point. When the pouring rain blends with her tears, it is the first moment in the film in which the environment is made to reflect the emotions of the character. This marks a rupture in the realist style of the preceding portion of the film. With Esther's death, 
Johan's suffering reaches a new level. This is the disparity that Schrader describes. There is no expression of the transcendent during disparity, but in the "decisive action" there is "an outburst of spiritual emotion totally inexplicable within the everyday." 31

The only scene in the film more shocking than Esther's death is her resurrection. At Esther's wake, Marianne goes in alone to see Esther's body, while the rest of the community is gathered in Johan's kitchen singing hymns. Marianne kisses Esther on the mouth, and then moves out of the frame. The camera stays on Esther's face and after several long moments, she begins to "wake up". Marianne's action, which brings Esther back to life, can be understood as the decisive action that Schrader describes. Schrader explains that the decisive action "breaks the everyday stylization; it is an incredible event within the banal reality which must by and large be taken on faith." ${ }^{32}$ The decisive action "freezes" disparity into stasis; there is no resolution to disparity. ${ }^{33}$ Although Esther is brought back to life, there is no resolution to the cause of her heartbreak, Johan's ongoing affair.

Stasis is demonstrated in Silent Light in the last shot of the film. The long take of the sunset and night sky, although not a frozen image, has a certain stillness. There is no obvious movement within the frame at any moment. While the everyday and disparity are experiential, stasis is formalistic, and Schrader states that a form is necessary to express the transcendent. ${ }^{34}$ The final scene in Silent Light formally expresses the transcendent through its moment of stasis, by moving away from the characters to focus on the sky. In fitting with Schrader's description of stasis, this last scene does not resolve the characters' conflict, or the disparity, but transcends it. 
Although Silent Light can be understood to exhibit the elements Schrader describes, there are some discrepancies between the film and his theory of transcendental style. The most significant complication arises with Schrader's concept of stasis, which is supposed to be the final stage of transcendental style. However, the last shot of Silent Light is an almost exact mirror of the first shot of the film. According to Schrader's terms, the process of transcendental style is linear, not cyclical, as is the case in Silent Light.

\section{The Influence of Ordet}

Nearly every review or article written about Silent Light notes that the film more than coincidentally resembles Carl Dreyer's film, Ordet. In interviews, Reygadas has addressed the relationship between the two films, and confirms that Silent Light is an homage to Ordet. He states that Ordet "is a film I love, and Dreyer is someone I adore and respect enormously. So yeah, it's [Silent Light] like a little brother to Ordet, but with a different essence." 35

Ordet is an adaptation of Kaj Munk's play, about a religious farming family in Denmark. The patriarch is Morten Borgen, who lives with his three sons: Mikkel is married to Inger; Johannes has become "mad" and thinks he is Jesus Christ; and Anders wants to marry a woman of a different Christian denomination. While the narrative in Ordet is quite different than Silent Light, there are numerous similarities between the films. Both feature a pastoral setting (and similar sounds of nature), religious families, a protagonist with religious doubts, and the death and resurrection of the protagonist's wife. Stylistically, the films share similar types of framing devices, which is noticeable in the location of windows in various shots, particularly in the resurrection sequence. In 
both films, the delivery of dialogue is peculiarly monotonous, but in Ordet, the characters rarely face each other or make eye contact when speaking to one another. Silent Light occasionally uses a similar frontality, most noticeably in the scene when Johan visits his father and seeks advice about his relationship with Marianne. Johan and his father (played by Cornelio Wall's real father, Peter Wall) stand side by side while talking. This scene also demonstrates the unusual framing Reygadas utilizes. In one shot there is a close up on Johan's father's face, while his eyes and the top of his head are outside of the frame. In the scene at the bathing pool, Esther is completely out of frame while Johan speaks to her, and when she first responds to him. In the first scene where Johan meets with Marianne, the camera follows behind his legs as he walks through tall grass and wild flowers. Scenes such as these indicate that there are more unusual uses of framing and camera movement in Silent Light in comparison to Ordet.

The most critical difference between the two films is that Silent Light ends without the spectator viewing Esther and Johan's reunion. This is a substantial change from Ordet, in which Inger and Mikkel have an emotional reunion in the final scene. The ending of Ordet seems to affirm religious belief, or more particularly, belief in miracles. Several scenes in the film feature dialogue about belief and the possibility of miracles. Mikkel, who had lost his faith, has no choice but to believe, now that his wife has been resurrected. Although Silent Light ends with a similar resurrection, the "message" of the film is less clear. This is partly because the conflict in the film is not resolved as it is in Ordet. In Ordet, each character finds some sort of peace: Johannes returns home and is himself again, no longer believing he is Christ; Inger is brought back to life and has a joyful reunion with Mikkel, who no longer feels abandoned by God; Morten has his 
family back together again; and Anders has been given the blessing of his father to marry. Despite the strangeness of events, the ending is quite conventional.

Silent Light ends with much less resolution. Although Esther is brought back to life, there is no onscreen reunion with Johan. Furthermore, it is unclear if Johan will leave Marianne completely and stay by Esther's side. Will Esther's death and resurrection change Johan's torment, or will he still be torn by his love for Marianne? One might assume that Johan's uncertainties about his faith will dissipate once he realizes that his wife has miraculously been brought back to life. Yet it is significant that Reygadas denies the spectator the certainty of resolution for Johan's conflicts. Because Johan is not faced with the miracle onscreen, it is less definitive that the film is advocating faith in the ineffable.

In the third chapter of Transcendental Style in Film, Schrader discusses the works of Carl Dreyer, including Ordet. Schrader contends that Dreyer does not use transcendental style as fully as Ozu and Bresson. For Schrader, Ozu and Bresson epitomize the use of transcendental style, as it is the only filmic style they employ. Dreyer, however, uses transcendental style only partially. Schrader claims that the later films of Dreyer's career employ transcendental style more than his earlier works, but that he was "never willing to completely forsake the expressive, psychological techniques at which he was also expert." 36

Schrader explains that Dreyer utilizes a combination of three kinds of film style in his work: Kammerspiel, expressionism, and transcendental style. In Ordet, unlike Dreyer's other films, transcendental style is what dominates. Schrader calls expressionism an "anathema" to transcendental style, but notes that both transcendental 
style and expressionism oppose Kammerspiel, yet also stem from it. ${ }^{37}$ He asserts that transcendental style "does not transform the external world ... it transforms the rationale of the world without changing its exterior." 38

Schrader comments that Dreyer's films often feature a character completely estranged from his environment. In Ordet, this character is Johannes, the middle Borgen son who believes he is Christ. Schrader discusses Johannes at length, and notes that the character is not the protagonist in the film, even though he performs the climactic miracle, bringing Inger back to life. There is no comparable character in Silent Light to Johannes, but to some degree, Johan mirrors Mikkel. Both Mikkel and Johan question the religious beliefs that are so intrinsic to their families. Both experience the loss of a wife. However, only Mikkel experiences a miraculous reunion with his wife. Because Ordet has more closure, the happy reunion between Mikkel and Inger is shown in the film's final scene. Furthermore, it is implied that Mikkel has regained his lost faith, because he has witnessed the miracle of his wife's resurrection. The main conflict for Johan is his love for Marianne and his commitment to his wife, Esther. He has not lost faith in God, but he is trying to reconcile his religious beliefs with his love and desire for Marianne. When Johan visits his father and seeks his advice, his father says, "What's happening to you is the work of the enemy, Johan." Johan responds, "I think it is God's doing." It is unclear whether Johan still believes this after Esther has died, and what he would believe after her resurrection.

Schrader states that the decisive action in Ordet is when Johannes brings Inger back to life. Johannes is the agent for the miracle, and Schrader asserts that Johannes is a "product" of disparity. ${ }^{39}$ Johannes' decisive action, the resurrection of Inger, does not 
result in lasting stasis. Schrader posits, "It is as if Dreyer carefully sets the viewer up for the Transcendent, then reveals the immanent." ${ }^{40}$ In Silent Light, it is Marianne who is the agent of resurrection. Johannes and Marianne have virtually nothing in common except for their role in raising the dead. In Silent Light, Marianne's action is perhaps atonement for the hurt she and Johan caused Esther. Moments after Esther “wakes up," Marianne leaves. She is no longer a feature of the film's action. Similarly, after Johannes resurrects Inger, he returns to the background of the scene. The focus of the post-resurrection is the reunion between Inger and Mikkel. Although not shown in Silent Light, the reunion of Esther and Johan is the anticipated event when the film ends. The most significant difference between Marianne in Silent Light and Johannes in Ordet is that Johannes is acting on behalf of God to resurrect Inger, while Marianne makes no reference to God as she brings Esther back to life.

Schrader states that disparity is caused by the tension between Kammerspiel, or naturalistic settings, and expressionism, or contrived camera composition and angles. ${ }^{41}$ Naturalism is evident in Silent Light but so are unusual camera angles and framing. Schrader also claims that the disparity in Ordet is proven by the decisive action, or the resurrection of Inger. He asserts that "the concept of a miraculous event within a carefully constructed banal reality" is more a part of transcendental style than Kammerspiel or expressionism. ${ }^{42}$

The focus of Schrader's distinction of Dreyer from Ozu and Bresson is the use of stasis. Schrader argues that Dreyer's films fail to achieve stasis, and that Dreyer's ambiguity of spiritual and psychological explanations for the decisive action prevent 
complete stasis. ${ }^{43}$ He also asserts that Dreyer prefers perpetual disparity over stasis, and uses disparity as an end and not a means. ${ }^{44}$

Schrader states that Ordet is the closest Dreyer comes to fully using transcendental style, yet he also terms the use of transcendental style in Ordet "selfconscious." 45 Ordet is almost completely void of expressionism, but uses Kammerspiel in relation to transcendental style. According to Schrader, Ordet has several elements of a Kammerspiel film: most of the action takes place indoors, within a fixed number of rooms, and between a fixed number of people. Certain scenes and conversations are repeated. The sets are naturalistic, with no exaggerated lighting, camerawork or acting. By comparison, much of Silent Light takes place outside. The conversations Johan has with his friend Zachariah and later with his father have some similarities, but are not as congruent as the recurring conversation about miracles in Ordet.

The influence of Ordet on Silent Light is significant, but it is how Silent Light diverges from Ordet that is of particular relevance to this thesis. The secular nature of Reygadas' film is noteworthy in relation to the religious aspects of Ordet. From the discussion of miracles to the agency of Johannes, Ordet presents the miraculous as something directly related to Christ. Silent Light, meanwhile, secularizes the miraculous, as indicated by the agency of Marianne, who has no connection to Christ.

\section{Materiality and Transcendence}

The love triangle between Esther, Johan, and Marianne, particularly in relation to the theme of redemption, is a part of the unusual way Silent Light conveys transcendence, and diverges from Ordet. One can argue that Johan is seeking redemption for causing his wife's broken heart and consequent death. However, it is Marianne, not Johan, who is the 
instrumental force in Esther's resurrection. Marianne expresses earlier in the film that she feels sorry for Esther, and wants to stop her affair with Johan. However, Johan and Marianne do not end their relationship, and Johan confesses this "relapse" to Esther moments before she literally dies of a broken heart. When Marianne first arrives at Esther's wake, her presence seems cruel and selfish. She tells Johan that she wishes to see Esther. While embracing Johan outside the house, Marianne stretches out her arm and her hand covers the sun in the sky. In "Carnal Spirituality: the Films of Carlos Reygadas," Tiago de Luca suggests that this is the moment Marianne gains the power to bring Esther back to life. Because the spectator does not yet know what is about to happen, the significance of this scene may be missed. Yet it has "supernatural overtones," and is reminiscent of an eclipse, "with the human limb standing for a celestial body of gigantic proportions." ${ }^{46}$ As de Luca's description of this scene indicates, Marianne's ability to resurrect Esther is ambiguous and never clearly explained. It is striking that although she belongs to a religious community, she does not pray to God, nor does she seem to represent God in her action.

In his essay, de Luca argues that Reygadas' films differ from the "spiritual and moral thrust" of the filmmakers who have influenced him, including Dreyer, Bresson, and Tarkovsky ${ }^{47} \mathrm{He}$ acknowledges that religion is at the core of Reygadas' films, just like the films that inspired him. However, for de Luca, Reygadas' films have a "surplus of materiality" that cannot point beyond to an "ineffable realm" but only point back to itself. ${ }^{48}$ De Luca claims, "Here the material often ceases to be the means for the attainment of a spiritual dimension to become itself the focus of attention.. ${ }^{, 49}$ De Luca sees Reygadas' focus on carnality as an obstacle for the kind of transcendentalism 
conveyed in the films of Dreyer and Bresson, and argues that in Reygadas' films, it is "the flesh that devours the spiritual." ${ }^{50} \mathrm{He}$ asserts that what separates filmmakers like Dreyer and Bresson from Reygadas is that "their attention to the physical was always subjected to its link with the spiritual world, 'the notion that one can only arrive at the essence of things through attention to their material surface."

Reygadas' focus on the material over the spiritual, as de Luca declares, can also be understood as a shift toward the secularization of a more traditional transcendental film, such as Ordet. Silent Light secularizes the most religiously significant part of Ordet, the resurrection scene. Through this scene, the film also diverges from Schrader's definition of transcendental style, in a way that complicates it being considered a transcendental film, and perhaps more generally, a religious film.

\section{Time and Transcendence}

One of the most striking ways in which Silent Light conveys transcendence is in its portrayal of time, particularly in relation to the miraculous. While most of the film displays features of realism, there is a strangeness in the depiction of time. The first shot, which begins with the stars in the sky and continues to show the sun rising, is mirrored by the last shot, which moves from the sun setting to the stars in the night sky. Richard Peña calls these shots the "parentheses" which encase the narrative of Silent Light. ${ }^{52}$ The shots themselves are several minutes in length, and while not close to the "real time" of a sunrise or sunset, they demonstrate the pace of the film and the way it uses time. The narrative of Silent Light is linear and generally straightforward in its unfolding. However, an unusual conception of time is indicated by the wall clock, which Johan stops at the beginning of the film. The clock is restarted near the end of the film by Johan's father at 
Esther's wake. The symbolism of the clock, and its audible ticking in the first scene at Johan's home is a reference to Ordet. In both cases, the clock is not keeping time for most of the film. When asked in an interview about the concept of time in Silent Light, Reygadas commented, "We stopped time to tell the story, a story that perhaps is only in our heads. When the old man fixes the clock, he is just fixing the time, he is making it correct; he is not making it go forward."53

The depiction of time in both Silent Light and Ordet is an expression of the motif of transcendence, yet the strangeness of time is more evident in Silent Light, through the opening and closing shots, and the indefinite nature of the narrative's timeline. It is unclear if the events in the film take place within days or over several months. The climate varies drastically, from the blazing summer heat when Johan is working on the farm, to the winter scene at Johan's parents' farm, to the autumn leaf that appears in the room after Johan and Marianne have sex. Cultural studies scholar Niels Niessen suggests in "Miraculous Realism: Spinoza, Deleuze, and Carlos Reygadas's Stellet Licht," that the events in the film take place between the sunrise and sunset of a single day. He points out that it is $6: 27$ am when Johan stops the clock at the beginning of the film, and 7:41 pm when Johan's father resets it. Niessen also references the extreme climate changes between scenes: "A bit more than thirteen hours of diegetic time are shown to have passed between sunrise and sunset, but during this day it has rained, snowed, and been warm enough to swim outside." 54 While the strangeness of time is evident in Ordet by the stopping and restarting of the wall clock, it is much more striking and complex in Silent Light. This is one indication of the ways a contemporary film like Silent Light may convey transcendence that is not expounded in Schrader's work. It is a transcendence of 
quotidian conceptions of time through temporal expansion and temporal indefiniteness.

\section{Transcendental Style and Art Cinema}

An important question surrounding the concept of transcendental style is whether there is actually a difference between films that fit Schrader's theory, and the majority of contemporary art cinema. The features of many "film festival films" are the tenets of Neorealism: non-professional actors, location shooting, diegetic sound, long takes, and so forth. All of these features apply to the films Schrader discusses in his text, and to contemporary films like Silent Light. What is distinctive about Silent Light in comparison to other realist art films is its point of departure from the real. The miracle at the end of the film is all the more baffling and powerful because there are no signs of the supernatural earlier in the film. There is no indication or even suggested possibility of a supernatural element before Esther's climactic resurrection. As Schrader explains, it is only because of the structure of the everyday that disparity can have such an impact on the spectator. In his essay, "From the Everyday to Stasis," Leo Bankersen comments that Silent Light "confronts" the spectator with "a real miracle". 55

Schrader acknowledges that elements of transcendental style, such as the decisive action or final stasis shot, are not exclusive to transcendental films. He asserts that elements of transcendental style are used in films that do not convey the transcendent, but most of these films do not use transcendental style exclusively. For Schrader, transcendental style cannot be mixed with other filmic styles and still be considered Transcendental Style in its ideal form, as utilized by Bresson and Ozu. Furthermore, he argues that it is the presence of all three elements, the everyday, disparity, and stasis, and the relationship between them that creates transcendental style. ${ }^{56}$ The primary example 
Schrader provides is Dreyer, whom he says uses transcendental style extensively but not "prescriptively" as do Ozu and Bresson. Schrader explains, "Transcendental style seeks to maximize the mystery of existence; it eschews all conventional interpretations of reality: realism, naturalism, psychologism, romanticism, expressionism, impressionism, and, finally, rationalism." ${ }^{, 57}$

A point Schrader reiterates throughout Transcendental Style in Film is the spirituality of the filmmaker. He seems convinced that only a spiritual filmmaker can produce a transcendental film. Regarding Dreyer, he contends that, "his doubts...stem from his fundamental doubts about the nature of the Transcendent in life and art." 58 Schrader states that there is an ambiguity in Dreyer's work, particularly in how the transcendent should be expressed. He claims that even as Dreyer moved toward more transcendental films in his career, he never forsook "his fundamental spiritual - and therefore stylistic - dualism." 59

The ambiguity and dualism Schrader describes of Dreyer is perhaps more common today, in films of the early $21^{\text {st }}$ century, such as Silent Light. Reygadas' film uses the transcendental style Schrader describes, but in a way closer to Dreyer than the complete, definitive use of the film style that Ozu and Bresson employ. At the same time, Ordet hardly seems ambiguous in comparison to Silent Light. The ending of Ordet is far more conclusive, as it provides resolution for each of the characters. Silent Light withholds such resolution and retains a sense of hesitation and ambiguity through its secularization. 
Reygadas has commented on the inconclusive aspect of his filmmaking, which he sees as an alternative to the majority of popular films that are narrative-driven and formulaic. He claims that his own films are driven by his intention to convey truth:

What I'm interested in - not dogmatically, but on an emotional level - are those brief moments in which the truth is experienced. The truth is never absolute; it's approached almost tangentially. Declaring a philosophical, religious, or social truth will turn it into dogma and therefore will prevent it from being experienced as real; it will always be normative. On the contrary, what feels real is poetic, ineffable, open-ended. Truth, by definition, is intangible. ${ }^{60}$

The open-ended ineffable truth Reygadas describes is how many contemporary art films employ transcendental style, in a way that is not obviously religious or spiritual. Silent Light is ultimately a film that uses transcendental style, but is not a transcendental film. It is an example of a contemporary use of transcendental style, which makes reference to a more classic transcendental film. It critically diverges from the seminal moment of transcendence in Ordet, and evades a religious explanation for Esther's resurrection. Marianne performs the action, and if anything, takes power from the sun to bring Esther back to life. She does not pray for it, or invoke God as Johannes does in Ordet. The ending of the film does not allow the spectator to witness Johan's reunion with Esther. Johan does not have the same renewal of faith that Mikkel experiences in Ordet, as Mikkel believes God is responsible for Inger's resurrection.

John Stuart Blackie's contention that high art is the most religious may be supported by Schrader and others who emphasize how the formal aspects of art cinema can create a spiritual experience, or expression of the transcendent. However, films such as Silent Light show that art cinema can convey ineffable truth through its formal 
elements while also averting religiosity, particularly at the moments when it is most anticipated.

\section{Notes}

${ }^{1}$ Paul Schrader, Transcendental Style in Film: Ozu, Bresson, Dreyer, (Berkeley: University of California Press, 1972), 3.

${ }^{2}$ Ibid.

${ }^{3}$ Ibid, 3-4.

${ }^{4}$ Ibid, 5 .

${ }^{5}$ Ibid, 6.

${ }^{6}$ Ibid.

${ }^{7}$ Ibid.

${ }^{8}$ Ibid, 8.

${ }^{9}$ Ibid.

${ }^{10}$ Ibid, 9.

${ }^{11}$ Ibid, 6.

${ }^{12}$ Michael Bird, "Film as Hierophany," in Religion in Film, eds. John R. May and Michael

Bird (Knoxville: University of Tennessee, 1982), 3.

${ }^{13}$ Ibid.

${ }^{14}$ Ibid, 13.

${ }^{15} \mathrm{Ibid}, 14$.

${ }^{16}$ Ibid.

${ }^{17}$ Ibid, 15-16.

${ }^{18}$ Leo Bankersen, "From the Everyday to Stasis," Film Krant, Feb 2009, http://www.filmkrant.nl/slowcriticism_2009/6804.

${ }^{19}$ Schrader, 39.

${ }^{20}$ Ibid.

${ }^{21}$ Ibid, 42.

${ }^{22}$ Ibid.

${ }^{23}$ Ibid.

${ }^{24}$ Ibid, 49.

${ }^{25}$ José Castillo, "Carlos Reygadas," Bomb 111 (Spring 2010), http://bombsite.com/issues/111/articles/3452.

${ }^{26}$ Ibid.

${ }^{27}$ José Teodoro, "Silent Witness: An Interview with Carlos Reygadas," Cineaste 34, no.2 (2009), http://www.cineaste.com/articles/emsilent-lightem-an-interview-with-carlos-reygadas.

${ }^{28}$ Richard Peña, "Transformations: New Spins on Spiritual Crisis and Growing Pains," Film Comment, July 2007, 66.

${ }^{29}$ David Jenkins, "Carlos Reygadas: Interview," Time Out, 2007, http://www.timeout.com/london/film/carlos-reygadas-interview-1.

${ }^{30}$ Castillo, "Carlos Reygadas."

${ }^{31}$ Schrader, 43. 
${ }^{32}$ Ibid, 46.

${ }^{33}$ Ibid, 49.

${ }^{34}$ Ibid, 51.

${ }^{35}$ Teodoro, "Silent Witness."

${ }^{36}$ Schrader, 112.

${ }^{37}$ Ibid, 118.

${ }^{38}$ Ibid, 119.

${ }^{39}$ Ibid, 134.

${ }^{40}$ Ibid, 136.

${ }^{41}$ Ibid, 120.

42 Ibid.

${ }^{43}$ Schrader, 121.

${ }^{44}$ Ibid, 144.

${ }^{45}$ Ibid, 132.

${ }^{46}$ Tiago de Luca, "Carnal Spirituality: The Films of Carlos Reygadas," Senses of Cinema 55 (2010), http://sensesofcinema.com/2010/feature-articles/carnal-spirituality-the-films-of-carlosreygadas- $2 /$.

${ }^{47}$ Ibid.

${ }^{48}$ Ibid.

${ }^{49}$ Ibid.

${ }^{50}$ Ibid.

${ }^{51}$ Ibid.

${ }^{52}$ Peña, "Transformations," 66.

${ }^{53}$ Karin Luisa Badt, "Silent Light or Absolute Miracle: An Interview with Carlos Reygadas at Cannes 2007," Bright Lights Film Journal, August 2007 Issue 57, http://brightlightsfilm.com/57/reygadasiv.php\#.UbpEoBalafQ.

${ }^{54}$ Niels Niessen, "Miraculous Realism: Spinoza, Deleuze, and Carlos Reygadas's Stellet Licht," Discourse, Volume 33, Issue 1, Winter 2011, 43.

${ }^{55}$ Bankersen, "From the Everyday to Stasis."

${ }^{56}$ Schrader, 52.

${ }^{57}$ Ibid, 11.

${ }^{58}$ Ibid, 112.

${ }^{59} \mathrm{Ibid}$.

${ }^{60}$ Castillo, "Carlos Reygadas." 


\section{Chapter Two}

Inner Demons: The Exorcism Film Genre and the Case of Requiem Believe nothing you hear, and only one half that you see. -Edgar Allan Poe

Religion has long been a prevalent feature of horror cinema. As theology scholar Bryan Stone asserts, the "persistent yet ambiguous relationship between religion and film is nowhere more evident than in the case of horror films." ${ }^{, 1}$ Religious studies scholar Douglas Cowan's contribution to The Routledge Companion to Religion and Film, "Horror and the Demonic," contends that horror is a significant marker of the intersection of religion and film, and holds a place in both the "artistic, technological, and economic development of cinema" and in the "history, evolution, and systemization of human religious consciousness." ${ }^{.2}$ However, Stone asserts that horror is largely neglected in religion and film scholarship, and is not considered a "serious partner" for discourses on religion and philosophy. ${ }^{3}$

Stone situates horror cinema within the context of secularization, and notes that while society is becoming more secular, "openness" to religious and spiritual matters does not seem to be waning. ${ }^{4}$ What is changing is the form of the religious, which Stone argues has been altered by late modernity.

It could even be argued that horror as a genre represents a loss of confidence in the institutions associated with the religious. While explicitly religious markers (priests, crucifixes, Satan, demons, etc.) are conventional in horror film, they are merely conventions - unhinged from a compelling moral vision and lacking the symbolic power required to engage us at the deepest level of our being and to shape our values and behavior. $^{5}$

A popular horror subgenre that utilizes the explicit religious markers Stone describes is the exorcism film, which often features a character believed to be possessed 
by demons, and an exorcist who attempts to cast out the demons. Exorcism films typically showcase disturbing, often grotesque images in conveying demonic possession, and sensationalize the Catholic ritual of exorcism. The pervasiveness of exorcism narratives in popular cinema indicates a contemporary fascination with exorcism. ${ }^{6}$ The position of the Catholic Church in modern society has changed and diminished over the last several decades. Despite this, or perhaps even because of this, audiences are intrigued by the ritual which is in many ways antithetical to activities belonging to the modern, secular world.

Films about demonic possession and exorcism are seemingly synonymous with horror films. However, Hans-Christian Schmid's film, Requiem (2006), approaches the usual exorcism narrative from outside the confines of the horror genre. Notably, Requiem maintains an ambiguity that neither affirms nor (completely) denies a supernatural element. This use of ambiguity contrasts with the conventions of the horror genre, which creates terror by demonstrating that the supernatural is real. Requiem's ambiguity functions similarly to the ambiguity of Silent Light, and ties it to conventions of art cinema. Although Requiem is less a formal art film than Silent Light, it similarly uses a realist style and treats its religious aspects ambiguously. To use film scholar David Bordwell's term, Requiem can be considered a "slice of life" narrative. ${ }^{7}$ The conflict facing the protagonist in both Requiem and Silent Light is internal, and the protagonists' familial relationships are crucial to this conflict. Both protagonists have religious faith, but in both cases, religion is not a solution to their problems. One significant difference between the two films is that in Silent Light, something occurs that cannot be naturally explained, while in Requiem, there is a possible natural explanation for events. 


\section{Genre Conventions}

The genre-defying aspects of Requiem are particularly evident in relation to The Exorcism of Emily Rose (Scott Derrickson, 2005), which is based on the same "true story" as Requiem. A comparison of the two films illustrates how it is the treatment of the story and not the story itself that makes Requiem so unique. Both films are inspired by the life of Anneliese Michel, a German woman who died in 1976 at the age of 23, after undergoing a series of exorcisms. The central question of both films is whether the protagonist was possessed or mentally ill. The approach each film takes, and the formal elements each employs, address this question in very different ways.

In Requiem, the protagonist is Michaela Klingler (Sandra Hüller), a young woman who moves away from her family for the first time to go to university. Michaela's parents (Imogen Kogge and Burghart Klaußner) are hesitant to let her leave, because she is on medication and has spent the last year recovering from what was diagnosed as epilepsy. The narrative is in some ways a typical coming-of-age story, as Michaela is so desperate to break away from her parents and experience life on her own. She takes a class in social pedagogy and wants to become a teacher, she befriends Hanna (Anna Blomeier), who is from the same small town, she goes to parties, and meets her first boyfriend, Stefan (Nicholas Reinke).

In The Exorcism of Emily Rose, the protagonist is Erin Bruner (Laura Linney), a lawyer assigned to the defense of Father Richard Moore (Tom Wilkinson). Moore is a priest charged with negligent homicide after performing an exorcism on a young woman named Emily Rose (Jennifer Carpenter), who died while in Moore's care. This American production is a much more conventional Hollywood horror film than Requiem. However, 
it too is a variation of the genre in that it is primarily a courtroom drama, and only shows the possession and exorcism in flashback.

The conventions of exorcism films arguably derive from the seminal film of the genre, The Exorcist (William Friedkin, 1973). The Exorcist is one of the most popular horror films of all time, both in terms of critical and commercial success. Therefore, every film about possession and exorcism made since then is compared to it. Based on the novel by William Peter Blatty, The Exorcist is about the possession of a young girl, whose non-religious mother, as a last resort, turns to a priest to perform an exorcism. Like The Exorcism of Emily Rose and Requiem, the possessed in The Exorcist, Regan (Linda Blair), is female, young, and innocent. In each of these films, there is a shift in at least one character's perception from doubt or agnosticism to belief in the supernatural. In The Exorcist, this character is Regan's mother, Chris (Ellen Burstyn), and in The Exorcism of Emily Rose it is Erin, the protagonist. This shift can also be understood as a move from a hesitation or ambiguity regarding the possession, toward a supernatural explanation. Notably, there is no such shift in the narrative of Requiem, but rather a sustained hesitation until the end of the film.

The pivotal character in The Exorcist is the priest who performs the exorcism, Father Merrin (Max von Sydow), and the younger priest who assists him, Father Karras (Jason Miller). The dynamic between Karras and Merrin is similar to that of Father Landauer (Walter Schmidinger) and Father Borchert (Jens Harzer) in Requiem. Karras is at first skeptical of Regan's possession, but when exorcism seems the only option, he assists Merrin, who has experience performing the ritual. In Requiem, Landauer is Michaela's parish priest who has known her all her life. She visits him when she first 
believes that she is possessed, and he dismisses her assertion, saying, "We believe in him [the devil], and in God, too, but they are symbols, examples for our orientation, not literal things." Landauer's statement is surprising, but also relatable to the doubts of The Exorcist's Karras. Despite his reluctance and skepticism, however, Landauer eventually brings the young priest Borchert to see Michaela. It is not clear if Borchert has performed an exorcism before, but he immediately is convinced that Michaela is possessed. Borchert affirms Michaela's belief about what is happening to her, and convinces Landauer and Michaela's parents that exorcism is necessary. In The Exorcism of Emily Rose, Moore is the only priest involved in Emily's case. In each film, there is some indication that at least one of the priests has recommended seeking a medical, or psychiatric explanation for the possessed individual. In Requiem, Landauer tells Michaela to see a psychologist when she describes the "hideous faces and voices" she is experiencing. In The Exorcism of Emily Rose, Moore brings a doctor to see Emily, and has him witness the exorcism. In The Exorcist, Karras reluctantly pursues exorcism after numerous medical tests and doctors' visits cannot aid Regan. The films to varying degrees convey the actual procedure outlined by the Catholic Church to allow for an exorcism to take place.

\section{Exorcism in the Real World}

According to the Compendium of the Catechism of the Catholic Church, an exorcism takes place when "the Church asks with its authority in the name of Jesus that a person or object be protected against the power of the Evil One and withdrawn from his dominion". ${ }^{8}$ This occurs as part of the rite of Baptism. However, only a priest who has been authorized by his bishop can perform a "solemn" or "major" exorcism. ${ }^{9}$ The Catholic Encyclopedia states that any priest may be called upon to perform "his duty as 
exorcist." ${ }^{10}$ The Encyclopedia notes that there are important stipulations to the rite. Possession should not be taken lightly, and caution must be exercised to distinguish between genuine possession and "certain forms of disease." ${ }^{11}$ Furthermore, the exorcist should avoid "everything that savours of superstition" and "leave the medical aspects of the case to qualified physicians." ${ }^{12}$ Exorcisms should ideally take place in a church, but if this is not possible, witnesses, preferably family members of the possessed, should be present, particularly if the victim is a woman. Other stipulations state that if expulsion does not occur, the ritual should be repeated. Details are provided of which sacred objects can be used during the rite, while the Eucharist must not be brought in case of "irreverence" by the possessed. The Encyclopedia even notes the garments to be worn by the exorcist. ${ }^{13}$

The rite of exorcism is, as depicted in exorcism films, a detailed procedure. Whether or not one believes that demonic possession is real, the ritual of exorcism is a very real and documented process. Media articles published about the release of various exorcism films often include discussion of the real aspects of the case depicted. Likewise, articles detailing relevant events in the Church include mention of recent exorcism films. Such is the case of an article in the Guardian about an exorcism conference in the United States in 2010, which was attended by dozens of American priests and bishops. The article features an image from The Exorcism of Emily Rose, and includes an interview with Father Gary Thomas, who the 2011 film The Rite (Mikael Håfström), is based on. Thomas, an American Catholic priest and experienced exorcist, was asked about the occurrence of exorcism in the United States, and the Church's requirements for recognizing a case of demonic possession. Thomas states that every diocese is supposed 
to have a designated exorcist, according to canon law. However, many do not, which he claims is a "result of the post-Vatican II church."14 Thomas emphasizes the screening process that discerns if a person actually is possessed or simply believes he or she is possessed. A team including a physician, clinical psychologist, and psychiatrist, who are all Catholic, must first rule out a medical explanation for the alleged possession. Thomas argues that part of the reason there has been an increased demand for exorcism in recent years is because people mistake mental illness for possession. Many requests for exorcism are assessed, but only a handful are actually brought to Thomas. He says he has performed exorcisms on only five people over five years, and some of these individuals decided to abandon the lengthy process, due to the need for repeated exorcisms. Thomas asserts that possession is not involuntary, and "you have to invite a demon in." ${ }^{15} \mathrm{He}$ claims that eighty percent of those who have requested exorcism have been sexually abused. He also states that "sexual abuse is a doorway for a demon" because the victim is so vulnerable. ${ }^{16}$

Interest in exorcism is not only found in secular media. A 2011 article published in U.S. Catholic argues that, "After a decades-long absence, interest in demonic possession - and the ritual to defeat it - is on the rise." ${ }^{17}$ The article, written by Daniel Burke, tells the story of a man in California who came to believe he was possessed, and who eventually underwent an exorcism performed by Father Thomas. Burke claims that there are now more exorcists in the United States than at any other time in modern history. He quotes history scholar Nancy Caciola, who argues that exorcism tends to gain prevalence when the Church is undergoing a time of crisis. ${ }^{18}$ There was a dramatic increase in materials printed about the rite during the papal schism of the $15^{\text {th }}$ century, 
and during the Protestant Reformation. With the Church's recent sexual abuse scandals, a more secular society, and significantly decreasing numbers of practicing Catholics in the West, Caciola argues it is an appropriate climate for the resurgence of exorcism. The number of exorcists in the United States increased dramatically during the later years of John Paul II's papacy, and even more so under the authority of Pope Benedict XVI. The priests chosen to be exorcists are usually theologically conservative, as are the bishops who appoint them. ${ }^{19}$ Burke states, "Exorcism reasserts the relevance of the church and its inimitable power over human destiny."20

\section{Thematics of Belief}

In Requiem, the Church is still very relevant for Michaela and her family, who are quite conservative. When Michaela walks in late to her first social pedagogy class, the professor puts her on the spot and asks what she believes in. She replies, "God," without any hesitation. The other students laugh and Michaela looks around surprised and embarrassed. The professor comments that they believe in nothing, "and that is the problem." Michaela's problem both is and is not her religious belief. Her belief is part of her identity, a connection to her values and morals and her familial upbringing. Even when she moves away for university and her parents are not around, Michaela continues to pray, use the rosary beads her mother gave her, and wear a cross around her neck. Her religious belief provides her with a sense of stability amongst all the change she experiences living away from home for the first time. However, it also complicates how she deals with her illness. She never consults with a psychiatrist, because she is already convinced that her ailment is supernatural, and cannot be helped through psychiatry. Even when Michaela is frustrated and angry about her situation, she never considers that 
it might not be a religious problem. Father Borchert affirms her beliefs and tells her that she is suffering because God chose her. Michaela relates her situation to St. Katharina of Biasca, and is comforted by the thought that Katharina's suffering served God. When she tries to convince Hanna to be a more dedicated student, Michaela gives her a book about Katharina, and tells her, "She did a lot of good in the time she was given." Hanna looks over the book and comments, "It says here God dictated it and that she resisted the devils and found redemption in death." Michaela wants her own suffering to have a greater purpose and mean something in the way she thinks Katharina's did. Near the end of the film, while Michaela is resting at her parents' house, she converses with Father Borchert about St. Katharina. Borchert asserts that Katharina "suffered for a higher purpose." Michaela smiles, and whispers, "A martyr."

In addition to the narrative, the theme of belief is expressed in Requiem through the formal features of the film. While other exorcism films direct the spectator toward belief by visualizing the supernatural, Requiem avoids any expression of a supernatural element. Therefore, if a spectator believes Michaela is possessed in the film, or at least could be possessed, it is the spectator's own interpretation of the film, and perhaps his or her personal beliefs, which account for such a reading. Alternatively, the film may be read as implying that Michaela was mentally ill. However, the fact that the film never confirms this leaves room for interpreting the narrative otherwise. Numerous reviews of Requiem comment on the film's hesitation regarding a natural or supernatural explanation. Peter Bradshaw notes that Requiem "declines simply to convict Michaela's parents or Michaela herself of being reactionary or irrational," and instead, "implies that her visions may not be amenable to the interpretative orthodoxies of either church or 
clinic." 21 Jeannette Catsoulis contends that Schmid "remains agnostic, suggesting that Michaela's problems, whatever their origin, prove only that a mind in torment is a terrible thing.,"22 Just as Michaela's friends and family, who witness her "episodes," come to differing conclusions about her condition, so may spectators interpret the film differently.

There is an interesting dichotomy between Michaela's university friends, Hanna and Stefan, and her parents and priests. Hanna and Stefan witness Michaela's deterioration at university, and are not at all convinced that she is possessed. Meanwhile, Father Borchert, and later Father Landauer and Michaela's parents, who have not seen her on a regular basis, judge her disturbing behaviour differently. Stefan is disturbed by Michaela's ecstatic dancing after completing her pedagogy essay, and her somewhat manic behaviour. She has stopped taking her epilepsy medication, and Hanna comments that she looks thin and unwell. Both Hanna and Stefan have seen Michaela pass out after either an "episode" or simply from exhaustion. Hanna finally tells Stefan to take Michaela to a hospital, but he is afraid she will be put in a "loony bin" and instead takes her home to her parents. Stefan witnesses Michaela's behaviour at home that fully convinces her parents that she is possessed and in need of an exorcism. However, it is unclear if Stefan also comes to believe that she is possessed. In The Exorcism of Emily Rose, Emily's boyfriend Jason (Joshua Close) testifies that she was possessed. Likewise, Emily's parents serve a different role than Michaela's parents in Requiem. In The Exorcism of Emily Rose, Emily's parents are only minor characters. They are portrayed as victims who entrusted Father Moore with the care of their daughter. In Requiem, however, Michaela's relationship with her parents is much more featured. In particular, her strained relationship with her insensitive mother likely caused her stress and 
worsened her mental state. Michaela's parents make the ultimate decision to have her undergo an exorcism and not to make her see a psychologist first.

Michaela is experiencing a time of significant change and stress in her life in the film. It is a common age for symptoms of mood disorders or other mental illnesses to appear. The changes in her life could be enough to explain the worsening of her mental state. Although she had seen a doctor and had tests, she never sees a psychiatrist as her father, Hanna, and Father Landauer advise her. Her parents are not educated about varying forms of mental illness, and are so shocked by her rude outbursts and deterioration that they cannot conceive any explanation but possession. Today, many people would recognize that severe mental illness could cause Michaela's symptoms. As opposed to other exorcism films, Michaela does not speak Latin, break her bones, or levitate. Her body contorts in unusual, but not impossible, ways.

\section{Art Cinema versus Hollywood Horror}

In many ways, it is what Requiem does not do that separates it from other films in the exorcism genre. In The Exorcism of Emily Rose, many scenes are darkly lit, take place at night, and feature an eerie red tint. At some points in the film, realism is notably sacrificed to maintain this sense of eeriness, such as when Emily is writing an exam in the evening, and there are no lights on in the classroom. Additionally, the film uses canted framing in scenes such as this, which furthers a sense of strangeness and serves as a contrast to the realist style of Requiem. Requiem is not brightly lit, but uses natural lighting, and most scenes take place during the day. The Exorcism of Emily Rose features an ominous musical score, which like most horror films, highlights and intensifies disturbing scenes, and creates a suspenseful anticipation of disturbing images. Requiem 
has no musical score, and the music it does use is mostly diegetic and appropriate to the film's 1970s setting. The song choices are never used for suspense, but suit the art cinema quality of the film. Eddie Cockrell comments in his review of Requiem for Variety that the "organ-heavy hard rock" of Deep Purple's "Anthem," along with the other songs in the film "create a mood at once secularly chilling and religiously resonant."23 "Anthem" is played at the dance where Michaela gets her first kiss from Stefan, and she dances alone in a kind of trance. The song is again played over the very last shot of the film, in which Michaela's face is peaceful, into the postscript describing her subsequent death, and the rolling of the end credits. There is a notable contrast between how the song helps convey Michaela's ecstatic mood when she is dancing, but also is playing as the spectator learns that she dies. "Anthem" has a tonal complexity that is fitting for both scenes, and particularly, as a link between the scenes.

\section{Authenticity and Realism}

Another significant theme of Requiem, and other exorcism films, is a preoccupation with the real, which can be analyzed in terms of authenticity and perception. Requiem begins with a title card stating: "Requiem is based on real events, but the characters and situations portrayed in the film are fictional." Similarly, The Exorcism of Emily Rose states from the outset "This film is based on a true story." Requiem was shot on Super16 and blown up to $35 \mathrm{~mm}$, which is evident in the grainy quality of the film. It looks like a film that was made when it was set, in the mid 1970s, which adds a sense of authenticity. This, combined with the hand-held camera movement, gives a documentary-like quality to the film. In an interview, Schmid states that he and Requiem's director of photography, Bogumil Godfrejow, intended the documentary feel 
of the film, "in which you get closer to the story." ${ }^{24}$ Conventional horror films such as The Exorcism of Emily Rose depict the supernatural with an emphasis on convincing the spectator that what seems unbelievable is actually real. By showcasing the supernatural, these films provide the "evidence" the spectator needs to overcome disbelief. In contrast, Requiem does not show the fantastical, but conveys realism in its naturalistic approach.

The first onscreen indication that Michaela is unwell happens while she is on a religious pilgrimage with her family, after her first week away at university. She wakes up early, goes downstairs to an empty room in the hotel and sits at a table, examining the new rosary beads her mother has given her. She lays the beads on the table, and a moment later, they fall on the floor. It is unclear from the angle of the shot if Michaela could have knocked the beads over, or if they fell off the table unprovoked. She reaches to pick them up, but cannot. Her hand stretches, but it is as if she cannot reach far enough. She becomes frightened, and stands and walks toward the window, and then collapses. This scene indicates Michaela's fear of what is happening to her, and that she thinks there is something external affecting her. However, the spectator does not see or hear what Michaela sees and hears. This is one of the most significant departures from the conventions of the genre. The spectator cannot be frightened by what is frightening Michaela. Each incident in the film that depicts what Michaela herself perceives to be supernatural and an effect of her possession is presented naturalistically to the spectator. There is nothing to convince the spectator that there is a supernatural element in the diegesis of Requiem. The effect of this is also that there is no horrific aspect to the film. At the same time, Requiem does not deny the possibility of a religious element. It simply 
does not provide evidence of one. One may perceive Michaela's episodes as being caused by demonic possession, as Father Borchert and her mother, and later her father, do.

The ambiguity of Requiem is not upheld in The Exorcism of Emily Rose.

However, the filmmakers have claimed that the film is ambiguous, and leaves the spectator asking questions. While it has the added element of a courtroom drama, and depicts the exorcism in flashback, The Exorcism of Emily Rose maintains most conventions of exorcism films, and more broadly, of the horror genre. The court case at the centre of the film revolves around the question, was Emily Rose possessed, or psychotic? The argument articulated by director Scott Derrickson, and his co-writer, Paul Harris Boardman in the film's DVD featurette, "Genesis of the Story," is that the film leaves it up to the spectator to decide what was Emily's real circumstance. ${ }^{25}$ However, this argument contradicts the cues the film itself provides. The typical elements of a horror film, including an ominous, non-diegetic soundtrack, direct the spectator's response and interpretation of events. Another convention of the genre involves showing the spectator what the protagonist sees. In The Exorcism of Emily Rose, Emily's visions of faces melting into aggressive, black bleeding eyes makes the spectator experience Emily's fear, and contributes to the sense that the visions are real.

The main issue is not that Emily experiences something supernatural, but that other characters do as well. Erin is rational and agnostic, and yet she experiences strange sounds and things moving autonomously in her home. Considering that Erin, Father Moore, and Dr. Cartwright (Duncan Fraser) have independent supernatural experiences, it is difficult to argue that Emily Rose is simply mentally ill. The corroboration of aspects of her experience convinces these characters, and the spectator, that a natural explanation 
does not suffice. Despite its twist on the genre, namely the courtroom setting and focus on the consequences of the exorcism, rather than the exorcism itself, The Exorcism of Emily Rose follows the horror conventions that use proof of the supernatural to create doubt and fear for the spectator. While the focus of the film is somewhat different, the end result is the same. This is perhaps why the film received mixed reviews, and was not embraced by most critics. David Gilmour's review for the Globe and Mail called it "a paint-by-numbers horror film without a shred of originality". ${ }^{26}$ At the same time, Mick LaSalle's review for the San Francisco Chronicle called it "the thinking person's demon possession movie." ${ }^{27}$ Interestingly, promotional posters for Requiem included a quote from Lee Marshall (Screen International) that called it "the thinking man's The Exorcism of Emily Rose."28

\section{Othering and Point of View}

Exorcism films, like other horror films, not only create terror through the depiction of the supernatural, but also through the othering of mental illness. Stephen Harper, a media studies scholar, argues in Madness, Power and the Media: Class, Gender and Race in Popular Representations of Mental Distress, that cinema continues "the historical othering of madness," and that especially in today's visual culture, people form their understanding of mental illness through the cinema. ${ }^{29}$ His chapter, "The Suffering Screen: Cinematic Portrayals of Mental Distress" explores the horror genre, which he calls "the most problematic cinematic genre" ${ }^{30}$ He notes a history of "otherness" in horror film, dating back to silent films such as F.W. Murnau's Nosferatu (1922). ${ }^{31}$ Harper acknowledges that Hollywood most often portrays mentally ill characters 
"sympathetically," but he argues that a focus on class, gender, and race reveals less favourable depictions of mental illness. ${ }^{32}$

In "The Suffering Screen," Harper investigates auteurist films that present challenging and "ideologically complex" images of mental illness. ${ }^{33} \mathrm{He}$ discusses films such as Harmony Korine's Julien Donkey-Boy (1999), and David Cronenberg's Spider (2002), and argues that these films demonstrate a significant change in recent cinematic representations of mental illness, namely, a shift in narrative point of view from the third to first person. ${ }^{34}$ Harper suggests that these films attempt to get "inside the heads" of their subjects. ${ }^{35} \mathrm{He}$ claims that the subjective viewpoint of such films has the potential to counteract the more prevalent objectification and othering of individuals with mental illness.

This subjective viewpoint is conveyed in scenes of The Exorcism of Emily Rose that show the spectator what Emily sees and hears, such as the black eyed faces. However, the film also shows how other characters perceive her. When Emily is writing an exam in a classroom full of students, she sees grotesque faces outside the window. A shot of the window from Emily's point of view shows the spectator what she is seeing. However, the next shot shows Emily reacting to what she has seen, but from the point of view of the other students, who think she is screaming at nothing. The faces in the window are not visible in the long shot of Emily standing in the classroom. This dichotomy between the first and third person serves the ultimate function of a horror film. The shots depicting the disturbing things Emily sees help the spectator relate to her fear, while the third person shots make her incomprehensible behaviour the cause of fear. This is evident in the scene when Father Moore enters Emily's room and she is eating insects 
on the floor and starts screaming. Requiem, on the other hand, never externalizes Michaela's perspective when she is having an "episode". This allows for a separation between what is real and frightening to her, and what the spectator perceives as real.

\section{Horror Cinema and "Divine Madness"}

To understand how Requiem defies genre classification and secularizes typical depictions of possession, it is worth examining the history of filmic portrayals of "divine madness." 36 There is limited literature on the subject of possession and mental illness in film, but Jacqueline Zimmerman's People like Ourselves: Portrayals of Mental Illness in the Movies, and Michael Fleming and Roger Manvell's Images of Madness: the Portrayal of Insanity in the Feature Film, offer some valuable observations. Zimmerman's text explores American films that "honestly" deal with mental illness, and challenge audiences' understanding of the subject. ${ }^{37}$ She notes that mentally ill individuals are often the object of exploitation in films, and that there is a tendency to portray a person with a mental illness as an outsider, someone who fascinates and horrifies. ${ }^{38}$ In the chapter "Divine Madness: Poets, Prophets, and Demons," Zimmerman states: "In various societies and cultures there have been associations between madness and the divine. At various times madness has been linked to possession by supernatural forces, sometimes inspired, sometimes demonic." ${ }^{39}$ While her statements are somewhat vague, they indicate the pervasive connection between religious possession and mental illness. Zimmerman notes the historical association between psychosis and supernatural forces. She references Plato and Socrates' discussion of the benefit of "divine madness," and the history of Christian mystics. Francis of Assisi and Theresa of Avila are two examples of well-known Catholic saints who wrote of their mystical experiences. The 
behaviour of these mystics resembled the trances and ecstasies of biblical prophets. ${ }^{40}$ In Requiem, Michaela prays to St. Katharina of Biasca, whose fictitious legacy resembles St. Catherine of Siena, another famous Christian mystic. Zimmerman notes that while "madness" can be divinely inspired, it can also be demonic. She asserts that horror films typically portray madness in a one-dimensional way, and names The Exorcist as "one of the most extreme expressions". 41

In "Possession as Madness," a chapter of Michael Fleming and Roger Manvell's text, the authors begin with the following assertion:

Science has advanced civilization to a new age of technology and rational understanding, yet however dominant our rational faculties seem to have become, we continue to be reminded that we are not so far from the notion of possession and the dark forces of the demonic as we would like to believe ... It is almost as if belief in the supernatural grows only with the growth of science. ${ }^{42}$

Fleming and Manvell note that films reflect society's fascination with the supernatural, and in particular, films featuring "possession as madness" tend to have box office success. ${ }^{43}$ The chapter on possession focuses on the psychiatric inquiry into possession. Fleming and Manvell examine the relationship between demonic possession, mesmerism, and hysteria, including Freud's work on the latter. They assert that "possession has been an underlying theme in both the popular and the cinematic realms, "44 and that belief in possession is still common in Western society. The authors discuss the history of films depicting either "somnambulistic" or "lucid" possession and contrast early films such as The Cabinet of Dr. Caligari (1920) and Dr. Jekyll and Mr. Hyde (1931) with The Exorcist. They claim that in the 1970s, the filmic theme of dissociation transitioned from multiple personality "back to its roots in possession." 45 Fleming and Manvell explain that The Exorcist is significant not only for establishing the 
exorcism film subgenre, but also for the affect it had on audiences. There were numerous reports of "traumatic neuroses and psychoses" experienced by spectators of the film. ${ }^{46}$ One study examined the beliefs of subjects before and after viewing the film. The general conclusion was that the subjects "believed more in the possibility of mystical events and questioned more their power to change events in their own lives," however; the film "did not increase their level of emotional disorder." ${ }^{47}$ Fleming and Manvell's discussion of The Exorcist notes the shift in the film from a psychological explanation to a supernatural one. They assert that Karras, as both priest and psychiatrist, is "the perfect transitional figure for moving us out of a scientific approach to an acceptance of the supernatural."48 Fleming and Manvell argue that the popularity of The Exorcist affirms a belief in possession, more so than the devil, and that there is a prevalent tendency to "ascribe undesirable feelings to the supernatural." 49 This is certainly the case in Requiem, where Michaela attributes her experience to demons rather than mental illness.

\section{Possession Syndrome}

The issues surrounding alleged demonic possession and mental illness have been approached from both a religious perspective and a psychological one. Most approaches focus on the binary of supernatural possession versus mental illness. However, transpersonal psychologist Stephen Diamond advocates an understanding of possession in which religious belief and psychology are not opposed. In Anger, Madness, and the Daimonic: The Psychological Genesis of Violence, Evil, and Creativity, Diamond includes a chapter titled, "The Possession Syndrome: Demonic or Daimonic?" suggests that belief in spirits and demons is an original form of psychopathology, as "both paradigms seek to make sense of mental illness and aberrant human behavior." 
He outlines the history of associating possession with mental illness, and emphasizes the significance of the etiology of possession, along with its subjective meaning for the affected individual. ${ }^{52}$

Diamond contends that there is always a natural explanation for what was once called demonic possession. He does not discuss the fact that some people today still believe in demonic possession. Instead, he argues that cases of contemporary possession are actually syndromes such as dissociative identity disorder, also known as multiple personality disorder. ${ }^{53} \mathrm{He}$ explains that in instances of multiple personality disorder, "subpersonalities" take possession of an individual's thoughts and actions. ${ }^{54}$ Diamond states that "amidst all the latest medical discoveries, one thing remains constant: we still seek to detect and identify the concealed sources of evil." $" 55$ Individuals suffering from various psychoses often have difficulty accepting a biological explanation, which shatters their subjective experience, and instead, they are drawn toward myths of demons and the devil. According to Diamond, calling these mental illnesses "possession" is not incorrect, because it means understanding the illness as a form of possession, and does not require belief in the supernatural. He describes psychosis as "possession syndrome," 56 and argues that what is sometimes termed "genuine possession" can be understood as "daimonic possession" or "madness." 57 Diamond explains that individuals experiencing psychotic episodes are disoriented and susceptible, which explains the acceptance of a supernatural explanation for their experience: ${ }^{58}$

Many, feeling possessed, manipulated, or controlled by something foreign to themselves, reflexively latch on to the literalized idea of the 'devil' or 'demons' in order to bestow meaning on their bewildering inner battle. ${ }^{59}$ 
This seems quite true of Michaela in Requiem. In addition to believing that she is possessed by demons, Michaela attempts to find meaning in her suffering by relating her experience to St. Katharina. Early in the film, Michaela and her family join their parish pilgrimage to San Carlo, a holy site dedicated to St. Katharina. Later, Michaela tells Hanna that St. Katharina died at age 33, and during a conversation with Father Borchert, she references that Katharina was a martyr. Interestingly, St. Katharina of Biasca is a fictitious saint. The details of her life and legacy provided by the film do not match any real saints with similar names. As mentioned previously, St. Katharina may be a reference to St. Catherine of Siena, who was a mystic and who died at age 33, but she was not martyred. It is perplexing why Schmid and screenwriter Bernd Lange chose to fictionalize this aspect of the narrative. It does seem significant that Michaela's devotion to St. Katharina causes her to accept her suffering as somehow serving God, and to therefore give up on medical treatment. Perhaps Katharina represents the misplaced belief that Michaela, her parents, and her priests, put in exorcism as the cure for her suffering. This is an indication of the secularization of the exorcism in Requiem, as the film suggests that the characters are putting their faith in something that is not real - both St. Katharina and possession by demons. Requiem's omission of the supernatural insinuates that the characters are wrong to believe exorcism is the solution for Michaela's problems.

The ending of the film avoids a strong criticism of the Church, or Michaela's parents. Unlike The Exorcism of Emily Rose, there is no doctor present during the exorcism in Requiem. It is also not confirmed that Father Borchert received permission from the bishop to perform an exorcism. The harm caused by the exorcisms, and the 
choice of her parents and priests to not seek medical attention is not fully realized on screen, and therefore seems less explicitly critical.

In the last scene of the film, Hanna takes Michaela away from her home to try to convince her to get psychological help instead of repeating the exorcism. Michaela is thin and feeble, and Hanna drives her to a nearby hillside where they sit and talk. Hanna thinks that away from the influence of Michaela's parents, she can convince her not to return home. However, Michaela is firm in her decision that she will continue with the exorcism, even though she may never get better. She tells Hanna, "There's a reason for it all." The strength of Michaela's belief is evident on her face in the last shot, as she sits in the passenger seat of Hanna's car, on her way home. She looks peaceful and content, and her expression conveys a sense of hope that she will get better. This makes the impact of the postscript all the more effective. It states, "Following a series of several dozen exorcisms, Michaela Klingler dies of exhaustion in her parents' home."

Schmid maintains an ambiguity about Michaela's condition, and her fate, up until the very end of the film. The realist aspects of the film, including the documentary-like camerawork, and the denial of sensationalism through avoidance of first person point of view, grotesque images, and special effects, are what maintain the ambiguity of Requiem, and thus distinguish it from other exorcism films. By avoiding the conventions of the horror genre, Requiem also avoids an affirmation of the supernatural. By secularizing the possession narrative, the film offers a very different, though subtle, critique of who was to blame for Michaela's death. In The Exorcism of Emily Rose, those who believe Emily are depicted as righteous. In Requiem, those who believe in Michaela's possession seem 
to cause her more harm than good. Neither medicine nor the Church is able to help

Michaela, and this is the ultimate tragedy of her story.

\section{Notes}

${ }^{1}$ Bryan Stone, "The Sanctification of Fear: Images of the Religious in Horror Films," Journal of Religion \& Film 5, no. 2 (Oct 2001), http://www.unomaha.edu/jrf/sanctifi.htm.

${ }^{2}$ Douglas Cowan, "Horror and the Demonic," in The Routledge Companion to Religion and Film, ed. John Lyden, (New York: Routledge, 2009), 404.

${ }^{3}$ Stone, "The Sanctification of Fear."

${ }^{4}$ Ibid.

${ }^{5}$ Ibid.

${ }^{6}$ Exorcism films released within the last three years include: The Rite (Mikael Håfström, 2011), The Devil Inside (William Brent Bell, 2012), The Conjuring (James Wan, 2013), The Last Exorcism (Daniel Stamm, 2010), and The Last Exorcism Part II (Ed Gass-Donnelly, 2013). ${ }^{7}$ David Bordwell, Ozu and the Poetics of Cinema, (Princeton: Princeton UP, 1988), 262.

${ }^{8}$ Compendium of the Catechism of the Catholic Church, Vatican: Libreia Editrice Vaticana, 2005, Section 1673,

http://www.vatican.va/archive/compendium_ccc/documents/archive_2005_compendiumccc_en.html.

${ }^{9}$ Ibid.

10 "Exorcist," The Catholic Encyclopedia, Vol. 5, New York: Robert Appleton

Company, 1909, http://www.newadvent.org/cathen/05711a.htm.

${ }^{11}$ Ibid.

${ }^{12}$ Ibid.

${ }^{13}$ Ibid.

${ }^{14}$ Susan McCarthy, "What Happens at Exorcism School?" Guardian, 21 Dec 2010. http://www.guardian.co.uk/commentisfree/belief/2010/dec/21/exorcism-conference-devilsdemons.

${ }^{15}$ Ibid.

${ }^{16}$ Ibid.

${ }^{17}$ Daniel Burke, "They're Baaack! What's behind the return of the exorcist," U.S. Catholic, June 2011, http://www.uscatholic.org/church/2011/05/theyre-baaack-whats-behind-return-exorcist.

${ }^{18}$ Ibid.

${ }^{19}$ Ibid.

${ }^{20}$ Ibid.

${ }^{21}$ Peter Bradshaw, Review of Requiem, Guardian, 17 Nov 2006, http://www.theguardian.com/film/2006/nov/17/worldcinema.drama.

22 Jeannette Catsoulis, Review of Requiem, New York Times, 20 Oct 2006, http://movies.nytimes.com/2006/10/20/movies/20requ.html?_r=0.

${ }^{23}$ Eddie Cockrell, Review of Requiem, Variety._27 Feb 2006, 34, http://variety.com/2006/film/reviews/requiem-3-1200518310/. 
${ }^{24}$ Daniel G. Cabrero, “An Interview with Requiem Director Hans-Christian Schmid," Vert!go Magazine Issue 5 (Nov 2006), http://www.closeupfilmcentre.com/vertigo_magazine/issue-5november-2006/requiem/.

${ }^{25}$ Scott Derrickson and Paul Harris Boardman, "Genesis of the Story," The Exorcism of Emily Rose, DVD, Sony Pictures Home Entertainment, 2005.

${ }^{26}$ David Gilmour, Review of The Exorcism of Emily Rose, Globe and Mail, 9 Sept 2005, http://www.theglobeandmail.com/arts/the-exorcism-of-emily-rose/article1123623/.

${ }^{27}$ Mick LaSalle, "Reality's a Slippery Thing When the Devil's Doing the Talking," Review of The Exorcism of Emily Rose, San Francisco Chronicle, 9 Sept 2005, http://www.sfgate.com/movies/article/Reality-s-a-slippery-thing-when-the-devil-s-doing2578024.php.

${ }^{28}$ Lee Marshall, review of Requiem, Screen International, 20 Feb 2006, http://www.screendaily.com/requiem/4026250.article.

${ }^{29} \mathrm{Ibid}, 59$.

${ }^{30}$ Stephen Harper, Madness, Power and the Media: Class, Gender and Race in Popular Representations of Mental Distress, (Houndmills, Basingstoke, Hampshire: Palgrave Macmillan, 2009), 60.

${ }^{31}$ Ibid, 90 .

${ }^{32}$ Ibid.

${ }^{33}$ Ibid, 65 .

${ }^{34} \mathrm{Ibid}, 70$.

${ }^{35} \mathrm{Ibid}, 71$.

${ }^{36}$ Jacqueline Zimmerman, People like Ourselves: Portrayals of Mental Illness in the Movies, (Lanham, MD: Scarecrow, 2003), xv.

${ }^{37}$ Ibid.

${ }^{38}$ Ibid, xiv.

${ }^{39}$ Ibid, 91.

${ }^{40}$ Ibid.

${ }^{41}$ Ibid, 106.

${ }^{42}$ Michael Fleming and Roger Manvell, Images of Madness: the Portrayal of Insanity in the Feature Film, (N.J.: Fairleigh Dickinson UP, 1985), 57.

${ }^{43}$ Ibid.

${ }^{44}$ Ibid.

${ }^{45}$ Ibid, 66.

${ }^{46}$ Ibid.

${ }^{47}$ Ibid, 67.

${ }^{48}$ Ibid, 68.

${ }^{49}$ Ibid.

${ }^{50}$ Stephen Diamond, Anger, Madness, and the Daimonic: The Psychological Genesis of Violence, Evil, and Creativity, (Albany, NY: State University of New York, 1996), 111.

${ }^{51}$ Ibid, 64.

${ }^{52}$ Ibid, 114.

${ }^{53}$ Ibid, 116.

${ }^{54}$ Ibid, 117.

${ }^{55}$ Ibid, 119.

${ }^{56}$ Ibid, 125.

${ }^{57}$ Ibid.

${ }^{58} \mathrm{Ibid}, 126$.

${ }^{59}$ Ibid. 


\section{CHAPTER THREe}

"There's a Storm Coming": Apocalypticism and the Fantastic in Take Shelter For even the very wise cannot see all ends. -J.R.R. Tolkien

In the book of Genesis, a vengeful God decides to wipe out the corrupt by flooding the earth. God chooses Noah, a "righteous man," to be saved from the flood, and instructs him to build an ark that will house his family, and "two of every kind". ${ }^{1}$ Noah trusts in God, follows his instructions, and as God promised, he and his family are saved. Noah is a notable figure in the Bible, the Torah, and the Qur'an, even though his story is just one of many apocalyptic narratives in these religious texts. He is an ordinary man in extraordinary circumstances, who plays a pivotal role in saving the human race from extinction, because of his faith and obedience. God tells no one but Noah what is coming, and therefore, only Noah and his family are able to prepare for the destruction of the flood. In Jeff Nichols' 2011 film, Take Shelter, God is not a character. There is no mention of sin, punishment, or salvation. However, much like the story of Noah, Curtis LaForche (Michael Shannon) is an ordinary man compelled to take drastic measures to protect his family from an impending doom that only he foresees.

Curtis is a man in his mid-thirties living in small town Ohio with his wife, Samantha (Jessica Chastain) and his six-year-old daughter, Hannah (Tova Stewart). He works for a sand-mining company with his best friend Dewart (Shea Whigham), who comments that Curtis has a "good life." However, things begin to unravel for Curtis when he starts having apocalyptic dreams and visions of a catastrophic storm. Like Noah in the book of Genesis, Curtis is the only one who thinks something disastrous is about to happen. Yet while Noah had direct communication from God and detailed instructions 
for how to build the ark, Curtis is given no such direction or context. He is therefore uncertain about the meaning or truth of his visions. Fearing he may be schizophrenic like his mother, Curtis researches mental illness at the local library, and sees his doctor, who refers him to a counselor. Although he attempts to respond to his visions in a rational way by acknowledging mental illness may be the cause, he is also compelled to act on them in a more extreme, less rational way. He uses his family's savings to expand the storm shelter in his backyard, gives away his dog, and asks that Dewart be moved to a different work project. Curtis knows that his behaviour is inexplicable, and that he is taking precautions based on no threat other than what he has experienced in dreams. He tries to reassure Samantha that what he is doing is worthwhile and in the family's best interest, but she is confused and disturbed by Curtis' irrational behaviour and lack of explanation. After suffering a seizure while sleeping, Curtis finally confesses to Samantha what he has been seeing. Samantha supports him as he continues to deal with the uncertainty about what is real, and prepares for two undesirable outcomes. Either he is mentally ill and his worsening condition indicates that he will soon not be able to provide for his family; or an apocalyptic storm is coming that, even with the protection of the storm shelter, threatens his family's survival.

There are several frameworks to consider in analyzing how Take Shelter engages with discourses of religion and film in terms of narrative, genre, and film style. Take Shelter in many ways defies genre classification, but can broadly be considered an apocalyptic film. The apocalyptic film is a substantial and ever-growing genre, particularly in the United States. Take Shelter's position as an independent American film, in the context of the prevalence of apocalyptic films in America, will be explored in 
relation to apocalypticism's intrinsic place in American ideology. One of the most crucial features of Take Shelter is the way it maintains a hesitation between a natural and supernatural explanation for events, and thus engages with Tzevetan Todorov's notion of the fantastic. Todorov's concept will be utilized as the primary tool of analysis for the style and structure of Take Shelter, along with how the fantastic complicates attempts to categorize the film as "religious". Take Shelter's hesitation is also significant in relation to Close Encounters of the Third Kind (Steven Spielberg, 1977), which Jeff Nichols has cited as a direct influence on the narrative of Take Shelter. Take Shelter will be juxtaposed with Close Encounters to illustrate how similar narratives featuring a prophetic protagonist differ so greatly because of how they approach the real.

Take Shelter is less of an art film than Silent Light or Requiem, although it shares in the ambiguous qualities of those films in terms of avoiding a religious explanation for events. Like Requiem, Take Shelter distinguishes itself from films with similar narratives through its ambiguous approach to what is real and what is imagined. However, Take Shelter shows Curtis' dreams and visions whereas Requiem does not show the strange things Michaela sees. Similar to Silent Light, Take Shelter profiles an ordinary family man who works outside, and features a pastoral setting. However, in Take Shelter, the environment is more directly tied to the source of conflict, the impending storm Curtis sees in his visions.

\section{The Pervasiveness of Apocalyptic Film}

The apocalyptic film genre has exploded in the last two decades, particularly in the United States. While the Cold War era produced numerous apocalyptic films, such as The Day the Earth Stood Still (Robert Wise, 1951), and Dr. Strangelove or: How I 
Learned to Stop Worrying and Love the Bomb (Stanley Kubrick, 1964), the end of the Cold War did not relieve a cinematic preoccupation with the end of the world. Instead, the number of films made about the apocalypse, and the broad range of genres they occupy, has only increased. Films made in the 1990s featured a variety of doomsday causes, such as the comet in Deep Impact (Mimi Leder, 1998), and the alien invasion of Independence Day (Roland Emmerich, 1996). Along with their large studio budgets and box office success, these films share a distinctly American perspective (the President of the United States is a major character in both films), and a focus on heroic individuals who ultimately avert the apocalypse.

Take Shelter, while distinctive, is a part of the ubiquitous genre of apocalyptic film. In a recent article for the Telegraph, Anne Billson writes that apocalyptic films in the 1990s "were a rarity to be savoured but now they are so common their impact has been lost." ${ }^{2}$ In 2013, films as varied in genre as the comedy This is the End (Evan Goldberg and Seth Rogen), action blockbuster Pacific Rim (Guillermo del Toro), and zombie film World War Z (Marc Forster), have presented diverse scenarios for the apocalypse, and differing conclusions. Other recent films, such as Seeking a Friend for the End of the World (Lorene Scafaria, 2012) and Melancholia (Lars von Trier, 2011) are unrelated in genre, tone, and style, but share a setting days before the inevitable end of the world. Both films end precisely at the moment of the earth's destruction, and do not leave a possibility of salvation as was typical in apocalyptic films of the 1990s. Additionally, post-apocalyptic narratives remain popular, with futuristic science fiction films such as 2013 releases Oblivion (Joseph Kosinski), After Earth (M. Night Shyamalan), and Elysium (Neill Blomkamp), all big-budget Hollywood productions. 
Apocalyptic and post-apocalyptic films are most often associated with action and science fiction, as film scholar Kirsten Moana Thompson notes. ${ }^{3}$ However, the genre is much broader than that, as evident in films such as the post-apocalyptic father-son story, The Road (John Hillcoat, 2009), based on the novel by Cormac McCarthy.

\section{Traditional versus Secular Apocalypse}

Countless films, including Take Shelter, may be labeled "apocalyptic," but as with the term "religious film," the category is determined by how one defines the label. Religious studies scholar Conrad Ostwalt examines the trends in scholarship on apocalyptic film, and contends that the genre often includes films that are classified uncritically. In his essay, "Apocalyptic," his contribution to The Routledge Companion to Religion and Film, Ostwalt argues that apocalyptic films should only be classified as such if they conform to one of two categories: those that "follow or respond to the traditional form/pattern of the religious apocalyptic genre (Jewish and Christian apocalyptic texts)," and those films in which "most of the traditional form is retained but without the sacred content or reference to sacred agency (thus the traditional apocalyptic form is secularized)". ${ }^{4}$ He explains that traditional apocalyptic works are informed by Jewish and Christian traditions, and have defining features "characterized by dreams, visions, and symbols that unveil the events associated with the end of the world." Ostwalt, intervention by God is an essential aspect of traditional apocalyptic films, as it is what "allows the end of history to be meaningful." $\mathrm{He}$ asserts that without a vision of "sovereign reality" beyond the world, there would be nihilism, or a world ruled by chance, which he argues is "the outcome the apocalyptic drama wishes to avoid."7 Ostwalt explains that traditional apocalyptic films need not literalize biblical events, but 
may convey events from traditional apocalyptic texts like the book of Revelation in a fictional way that makes them more understandable and relevant. ${ }^{8}$

According to Ostwalt, secular apocalypse films may borrow traditional apocalyptic symbols and themes, but avoid any depiction of a "supernatural sovereignty". ${ }^{9}$ Additionally, secular apocalypse films tend to feature an evil force that threatens the world, rather than God as the cause of destruction, as in the story of Noah's ark. Perhaps the most significant distinction between traditional and secular apocalyptic works is that in secular apocalyptic films, the annihilation of humanity is ultimately avoided, often due to the actions of a heroic protagonist. In traditional apocalyptic works, the apocalypse is unavoidable, and "welcomed by the righteous community and initiated by the heroic divinity." 10 Ostwalt states that according to his own definition, The Matrix (Andy Wachowski and Lana Wachowski, 1999) is a secular apocalypse film. His example of a traditional apocalypse film is Left Behind (Vic Saren, 2000), a film about the Rapture produced by Christian film company, Cloud Ten Pictures.

Interestingly, Take Shelter fits neither of Ostwalt's categories for apocalyptic films. Divine intervention is not a part of Take Shelter, as there is no indication that God is responsible for Curtis' visions or the storm itself. At the same time, the film does not feature evil forces threatening humanity, nor a heroic figure who saves the world from obliteration, and therefore cannot be considered a secular apocalypse film, according to Ostwalt's definition. This indicates the limitation of Ostwalt's categories, and also highlights the fact that Take Shelter is a film that defies such genre classification. 


\section{Apocalyptic Dread}

The popularity of apocalyptic films is reflected in the wealth of literature on the genre, which tends to focus on contemporary works, and American-made films. In Apocalyptic Dread: American Film at the Turn of the Millennium, film scholar Kirsten Moana Thompson explores the prevalence of American apocalyptic films in the last decade of the $20^{\text {th }}$ century, and the first decade of the $21^{\text {st }}$ century. She asserts that in the 1990s, existent apocalyptic anxieties about the year 2000 became more apparent in American popular culture, journalism, and public policy. ${ }^{11}$ Thompson notes that this apprehension surrounding the new millennium and the apocalypse "drew upon longstanding eschatological prophecies about Armageddon drawn from Revelations, Daniel, and other Christian and Jewish apocalyptic texts." 12 She uses the term "apocalyptic dread" to refer to feelings of fear and uncertainty surrounding "global catastrophe."13 Thompson contends that apocalyptic dread of the 1990s and 2000s was a contemporary indication of the historic tradition of apocalypticism in America. She states that American apocalypticism is "a blend of providential and messianic elements in Puritan Calvinism," that first became apparent in Cold War era science fiction films, and reached a "hysterical peak" in the 1990s through a series of horror, disaster, and science fiction films that featured anxiety and anticipation of the new millennium. ${ }^{14}$ Thompson further argues that end of the world anxieties intensified rather than dissipated after the year 2000, due to 9/11 and surrounding fears of terrorism. ${ }^{15}$ According to Thompson, a prevalence of explicit religious content in Hollywood doomsday films developed around the turn of the $21^{\text {st }}$ century, "In part reflecting the increasing cultural conservatism of the recent era and the conservative commercial imperatives of their conglomerate parent companies". ${ }^{16}$ 
As Thompson's comments about anxieties and apocalyptic films indicates, each decade produces a new or modified set of anxieties that can account for a preoccupation with the end of the world. While apocalyptic films of the Cold War era were considered a reflection of atomic bomb fears, doomsday films of the 1990s were linked to uncertainties about the year 2000, and post-9/11 films about global disasters were related to anxieties about terrorism. In many reviews and articles about Take Shelter, the film is discussed as a reflection of the current age of anxiety, which many link to economic crises since 2008. Robert Koehler introduces his interview with Nichols, declaring, “Unlike any recent American film, Jeff Nichols' Cannes Critics Week winner Take Shelter gives expression to an extremely nervous country." ${ }^{17}$ In a review for Time Out, Tom Huddleston contextualizes Take Shelter within "cinema's response to the recent economic slowdown" and states, "When future film historians look back at the cultural fallout from America's financial collapse, Take Shelter will be a key text."18 Jeff Nichols has stated that his inspiration for writing Take Shelter came partly from personal feelings of anxiety, as well as a widespread societal anxiety of recent years.

There's this free-floating anxiety that we generally experience: you wake in bed and maybe worry about what's happening to the planet, to the state of the economy, to things you have no control over. In 2008, I was particularly struck with this during the beginning of the financial meltdown. Then there's a personal anxiety. You need to keep your life on track - your health, your finances, your family. I was in the first year of my marriage ... I was pondering that since a certain amount of anxiety comes out of one's marriage, then perhaps anxiety is born out of things that can be lost. ${ }^{19}$

\section{American Apocalypticism}

Literature on apocalyptic narratives tends to focus on American films, likely because so many apocalyptic films are American productions, set in the United States, 
and feature an American protagonist. Furthermore, there is an inherent preoccupation with the end of days in the United States that is rooted in the nation's religious history. In a review of Take Shelter for Religion Dispatches, Jay Michaelson comments that two thirds of Americans believe the world will end or radically change within their lifetime, and that more than half of Americans believe the Second Coming will be before the year $2050 .^{20}$

In “"Thy Kingdom Come’: Apocalypticism in American Culture,” religious studies scholar Randall Balmer states that Americans have always been fascinated with the end of the world, and the particular role they would play in it. ${ }^{21}$ Balmer asserts that apocalypticism can be a means of protest against established institutions, "as a call for religious revitalization, ${ }^{, 22}$ and notes its occurrence throughout American history:

In the nineteenth century, as Americans sought to define their place in the world, apocalyptic visionaries asserted that the United States stood at the center of the world, at least in God's eyes. In the twentieth century apocalyptic dualism and militarism - this adversarial, bomb-shelter mentality - meshed nicely with the titanic struggle between the superpowers, a struggle defined by Americans - preachers and politicians alike - as a showdown between good and evil. ${ }^{23}$

David S. New states in Christian Fundamentalism in America: A Cultural

History, that more than half of Americans believe the prophecies in the book of Revelation "will literally come true." ${ }^{24}$ New argues that the United States holds a religious idealism that is unique to that country, and is pervasive through the nation's culture and history. He claims "the very idea of the nation - held by both liberals and conservatives - involved the concept of the United States as God's chosen nation, God's chosen people, chosen to have a special role in his plan for humanity." $25 \mathrm{New}$ contends that America has always seen itself as a "religious entity," and points to the phrases "in 
God we trust," and "one nation under God" as evidence of this. ${ }^{26}$ New also claims that apocalypticism has significant power in the United States, and comments "how quickly, in times of crisis, it can move from the periphery to the center of public consciousness," such as during the Persian Gulf crisis. He notes that during that particular time, apocalypticists were featured on national news networks to explain the situation in the

context of biblical prophecy, and that apocalyptic books sold millions of copies. ${ }^{27} \mathrm{New}$ asserts that, "to this day apocalypticists remain on red alert". ${ }^{28}$

The work of New, Balmer, and other religious historians offers a convincing explanation for the popularity of American apocalyptic films. It also makes the case of Take Shelter all the more interesting. While the film engages with the anxiety and uncertainty that is common to the apocalyptic genre, it avoids much of the religious content that also permeates the genre, including discussion of the afterlife; Christ figures; miracles; themes of redemption and salvation, and so forth. It is extremely rare for a film that presents the possibility of apocalypse to not do so in a somewhat religious context, considering the American preoccupation with the end of the world exists largely through a religious lens.

\section{Ambiguity and the "Religious Film"}

As much as predicting the end of the world may seem ridiculous to some people, the fact is that a sizable portion of Western society, particularly American society, believes in it. Jay Michaelson notes the complicated correlation between religious belief and mental illness, which is a pivotal issue in Take Shelter: "If one person believes the world is about to end, we assume he is crazy. If a thousand believe it, they have religious conviction." 29 While some reviews of Take Shelter mention a religious aspect or 
interpretation of the film, none label it a "religious film." Even Christian film reviews do not claim the film as one that affirms religious belief. Curtis' doubts about his visions, and a lack of clear confirmation of his belief, make him a more complicated figure than a protagonist like Joan in The Passion of Joan of Arc (Carl Dreyer, 1928). Like Curtis, Joan is perceived as mentally ill by other characters. However, Dreyer's film is often heralded by Christians for its depiction of unwavering faith and piety in the face of skepticism. ${ }^{30}$ This is because The Passion of Joan of Arc does not hold the same ambiguity as Take Shelter when it comes to its religious content. In light of its surprising and ambiguous ending, Take Shelter can be interpreted in a number of ways. Its lack of definitive meaning is what distinguishes it from more explicitly religious films.

\section{Perceptions of the Prophet}

In several interviews, Jeff Nichols has named Close Encounters of the Third Kind as one of his favourite films, and has said that he admires how Steven Spielberg depicts middle class American life in the film. ${ }^{31}$ Despite substantial disparities in genre and style, there are notable similarities between the narrative of Close Encounters of the Third Kind and Take Shelter, mainly in the circumstances of the protagonist, and to a lesser extent in the dichotomy of belief versus mental illness that the film employs. In one interview, Nichols states that the protagonist of Close Encounters was a "model" for Take Shelter. ${ }^{32}$ Like Curtis in Take Shelter, Close Encounters centres on a working-class husband and father in the Midwestern United States who experiences something unbelievable. Roy Neary (Richard Dreyfuss) lives in Muncie, Indiana, where, while responding to a late night work call, he sees a UFO. He wakes up his family and drives them to the site, hoping to share with them the incredible thing he has witnessed. Roy says to his wife 
Ronnie (Teri Garr), "I need you to see something with me. It's really important.” Ronnie indulges Roy, but what Roy saw does not reappear. In the following days and weeks, Roy becomes obsessed with the image of a mountain from a recurring vision he has had since the sighting, and tries to recreate its shape first with a mound of mashed potatoes and then with dirt and debris from his yard. Disturbed by his erratic and self-absorbed behaviour, Ronnie loses patience, takes the children, and leaves Roy.

Roy's unwillingness to consider the impact of his obsession on his family make him seem like a poor husband and father compared with Take Shelter's Curtis. Unlike Roy, Curtis tries to keep up with his familial responsibilities. Even though he creates tremendous tension with Samantha by losing his job and therefore the insurance to cover a cochlear implant for Hannah, he is still very much engaged with his family, and believes that what he is doing will save them. By contrast, Close Encounters is more about Roy as an individual. At the very end of the film, Roy's obsessive belief is rewarded, as he meets the extraterrestrial creatures, and decides to go with them. His family is completely absent from the latter half of the film, and Roy never mentions them. The most important thing to him is to have his experience corroborated, and shared. When he cannot share his experience with Ronnie, their marriage falls apart. Instead, he bonds with Jillian (Melinda Dillon), a single mother whose son has been abducted, and who also has visions of a mountain.

While Curtis and Samantha's marriage in Take Shelter suffers because he cannot share his experience with her, they both make sacrifices to keep their family together. When a storm hits, Samantha follows Curtis into the shelter, puts on a gas mask, and waits. After several hours, when she is confident the storm is over and there is no threat, 
she asks Curtis to unlock the shelter door, and says, "This is what it means to stay with us. This is something you have to do." Curtis is not convinced that the threat has passed, but he trusts Samantha, and opens the door. Although his action means acknowledging that he was wrong, he is willing to do it for his wife and daughter. This scene, along with the final scene of the film, displays the greatest contrast from Close Encounters. Curtis' experience is shared with Hannah and Samantha, and the film ends with the three of them together, emphasizing that Take Shelter is ultimately about marriage and familial relationships, rather than individualistic belief.

A significant commonality between Close Encounters and Take Shelter is the depiction of the protagonist as a prophetic figure. Religious studies scholar John W. Martens writes that the prophets of the Bible were "ecstatic visionaries," and claimed a relationship with God, which allowed them to speak with authority. ${ }^{33}$ The only scene where Curtis actually prophesies is at a Lions Club supper, when he is surrounded by his neighbours and former coworkers. Having just been fired from his job, he quietly sits and eats with his wife and daughter. However, he is confronted by Dewart, who has learned that Curtis asked for him to be removed from his team at work. Dewart attacks Curtis, and the two men fight, culminating in Curtis flipping over a table, and addressing the crowded, now silent room. Curtis yells at the group, "You think I'm crazy? Well, listen up, there's a storm coming like nothing you've ever seen, and not a one of you is prepared for it." This is perhaps the most disturbing and uncomfortable scene in the film. One can see how others view Curtis and how he really may be unstable. Curtis mentions nothing about God, sin, or punishment, but tries to warn his neighbours, in a desperate way, that something terrible is about to happen. 
Roy in Close Encounters seems to have more in common with the biblical prophets, except that he is prophesying about extraterrestrial beings returning to earth, rather than the Second Coming of Jesus Christ. Martens comments that "The problem with determining true or false prophecy when it concerns the events of the future is that you simply have to wait for the results. Sometimes the results came too late for the prophets to save themselves." 34 In Take Shelter, it appears that Curtis has been proven a false prophet when the storm that sends him and his family into the backyard shelter turns out not to be the cataclysmic event he was expecting. In Close Encounters, the spectator knows that Roy is not a false prophet, but every character that has not shared some aspect of Roy's experience disbelieves him. In a review of Take Shelter for the Journal of Religion \& Film, Dereck Daschke notes the similarities between ancient prophets and Curtis' circumstances: "as absurd as the message may seem, the recipient of the revelation is compelled to act according to it; it is more real than dream."35

The protagonists in both Close Encounters and Take Shelter struggle with the desire to have their unbelievable beliefs verified, for Roy, that he did see an extraterrestrial spaceship, and that it is soon to return, and for Curtis, that the apocalyptic storm from his dreams is an imminent and very real threat to the survival of his family. Unlike Curtis, Roy is completely convinced that what he saw is real. While his family and neighbours think he is mentally ill, the spectator knows that Roy is not. The UFO cannot be just a creation of Roy's mind, as it is visible in the background of a shot before Roy is even aware of it. Furthermore, several others see what Roy saw, including Jillian, and Lacombe (François Truffaut), a scientist who is part of the effort to uncover and prepare for the extraterrestrial landing at the end of the film. In a review of Close 
Encounters for the New York Times, Vincent Canby writes that the end sequence, in which the extraterrestrial creatures are revealed, "has been deliberately designed to suggest a religious experience of the first kind. Whether or not you believe it, this climax involves the imagination in surprising, moving ways."36

Reviews of Take Shelter tend to avoid discussing the film in explicitly religious terms, although some do refer to it as a spiritual film. ${ }^{37}$ Several critics remark on the apocalyptic aspect of the film, and how it differs from other films in the genre. Alissa Wilkinson writes in a review for Christianity Today, "Too many directors exploit apocalyptic visions for cheap scares; Nichols hides nearly everything from us, making us feel rather than see what Curtis is experiencing." 38

The most significant distinction between Close Encounters of the Third Kind and Take Shelter is the use of ambiguity in the latter. In Close Encounters, as Vincent Canby suggests, the ending has an obvious religious connotation. Take Shelter, however, is ambiguous in its meaning, and evades the religious reading Close Encounters invites. Take Shelter's use of hesitation leaves the spectator unsure whether Curtis is a prophet, or is mentally ill. As previously mentioned, the depiction of the UFO in Close Encounters, as well as Roy's experience being shared by other characters, prevents such uncertainty. In other terms, the disparity between Take Shelter and Close Encounters is that the former can be considered a "fantastic" film, while the latter is not compatible with the fantastic genre.

\section{The Fantastic}

Tzvetan Todorov's seminal text, The Fantastic: A Structural Approach to a Literary Genre, explores a mode of fiction defined by its ambiguity. The fantastic occurs 
when it is unclear if the events of a story are real or imagined, natural or supernatural. Todorov discusses the fantastic as a literary genre, but it is also applicable to film. The spectator is uncertain if events that seem unbelievable and unnatural are actually taking place within the world of the film, or if they are illusory. Todorov writes that the fantastic "occupies the duration of this uncertainty." 39 Fantastic events "cannot be explained by the laws of this world," and therefore the individual experiencing this ambiguity is either a victim of illusion, or the event is real "but this reality is controlled by laws unknown to us". ${ }^{40}$ Once one realizes the truth of the situation, the fantastic no longer exists. According to Todorov, the film is then either uncanny or marvelous.

The fantastic is a useful method for analyzing Take Shelter, and allows one to consider how Nichols' film is distinguishable from other apocalyptic films, and prophetic films (like Close Encounters of the Third Kind), and more broadly, the types of films considered "religious." Take Shelter differs from films that are explicitly religious or in some way affirming of faith, because it is not conclusive. It does not advocate religious belief the way one might expect a "religious" film to do.

Todorov states, "The fantastic is that hesitation experienced by a person who knows only the laws of nature, confronting an apparently supernatural event." ${ }^{41}$ This describes the experience of Curtis in Take Shelter, and by proxy, the experience of the spectator. The fantastic "implies an integration of the reader into the world of the characters" and that world is defined by the ambiguous perception of the reader (or spectator). ${ }^{42}$ Todorov explains that there are three conditions for the fantastic. Firstly, the spectator must remain in a state of hesitation between a natural and supernatural explanation, and "the text must oblige the reader to consider the world of the characters 
as a world of living persons". ${ }^{43}$ Secondly, the spectator's hesitation may be shared by a character in the film, "thus the reader's role is so to speak entrusted to a character". ${ }^{4}$ According to Todorov, the hesitation of a character in the story is not a necessity of the genre, but may occur. In Take Shelter, the spectator's hesitation and uneasiness are enhanced by Curtis' uncertainty, and the way the film showcases his point of view. Thirdly, "the reader must adopt a certain attitude with regard to the text," namely, a rejection of an allegorical or poetic reading of the narrative. ${ }^{45}$ If one accepts a film as an allegory, the hesitation and uneasiness created by the fantastic do not exist. The power of the fantastic comes from not being able to "explain away" the events. Interestingly, several reviews of Take Shelter label the film as an allegory. A.O. Scott's review for the New York Times calls the film "a perfect allegory for a panicky time." ${ }^{46}$ As Scott's comment indicates, there is an allegorical aspect of Take Shelter tied to its depiction of anxiety. However, the film's hesitation and ambiguity are more dominant than its allegory, and it is therefore more aptly considered a fantastic film.

Whether or not a work of fiction is fantastic is largely determined by the ending of the story. If the spectator's hesitation remains after the film has ended, the film is fantastic. However, if by the end of the film, the spectator decides, "whether or not what they perceive derives from 'reality' as it exists in the common opinion," then the film is ultimately either uncanny or marvelous. ${ }^{47}$ If "the laws of reality remain intact and permit an explanation of the phenomena described" the work fits the genre of the uncanny. ${ }^{48}$ However, if "new laws of nature must be entertained to account for the phenomena" the work is of the marvelous genre. ${ }^{49}$ 
The most significant scene of Take Shelter is its very last, as the meaning of the film, however one chooses to interpret it, is determined by this scene. After meeting with a psychiatrist, Curtis, Samantha, and Hannah take their summer vacation at Myrtle Beach. They have accepted that once they return to Ohio, Curtis will need to begin treatment for schizophrenia. There is a sense of calm and resolution at this point, as despite the fact that Curtis has been diagnosed with a mental illness, he still has the support of his family, and they are together and at peace. Curtis is building sand castles on the beach with Hannah, while Samantha is cooking inside their cottage. Hannah looks up and stares at something out in the water, and signs to Curtis that it is a storm. Curtis turns to see what Hannah sees, and it is an incredible storm, with multiple tornado funnels forming on the horizon. Unsure if what he is seeing is real, Curtis turns to Samantha, who has come outside. Samantha's face expresses that she too sees the storm and recognizes its significance. Once she acknowledges what Curtis has seen, everything changes. Curtis picks up Hannah, and walks over to Samantha, reaching for her hand. Although they are not at home where his storm shelter is fully prepared, Curtis seems in control and prepared to handle the situation. Samantha is shocked and amazed by the sight of the storm, but also realizes that it is just as Curtis had predicted, and this also perhaps gives a sense of acceptance. Curtis says her name, calling her back inside the cottage, and her simple response is "Okay." While the ending suggests that the incredible destruction Curtis predicted is real, and threatens them all, there is also a sense of justification, because Curtis has been proven right, and most importantly, gets to realize this with his family. Had he been alone on the beach, he may not have been able to accept that the storm was real. Notably, this scene mostly features shots of Samantha, as she 
reacts to seeing the storm and feeling the oily raindrops on her hand. This suggests that the storm is not another one of Curtis' visions, as it is mostly seen through Samantha's eyes.

Todorov outlines two subgenres of the fantastic: the fantastic-uncanny and the fantastic-marvellous. In the fantastic-uncanny, events that seem beyond reality eventually are given a rational explanation. If Take Shelter had ended with its second-to-last scene, in which Curtis and Samantha visit a psychiatrist who confirms that Curtis has a mental illness, the film would be considered fantastic-uncanny. Mental illness, which is one of two possible explanations put forth in the film, would rationally explain the supernatural quality of Curtis' visions. Todorov explains, "Doubt is sustained up to a point, between the existence of the supernatural and a series of rational explanations" which are described in relation to the imaginary and the illusory. ${ }^{50}$ Explanations such as accident or coincidence; tricks and prearranged apparitions; and illusion of the senses would be illusory, while dreams; "madness;" and the influence of drugs would be rational explanations for the imaginary.

Alternatively, Take Shelter can be considered fantastic-marvellous if the spectator interprets the final scene as proof that the apocalyptic storm Curtis prophesied is real. Fantastic-marvellous narratives are presented as fantastic but end with an acceptance of the supernatural. Todorov claims such narratives are closest to the "pure" fantastic, in which "by the very fact that it remains unexplained, unrationalized, suggests the existence of the supernatural." ${ }^{51}$ If one interprets the final scene of Take Shelter as real, and not illusory or imagined, then the film is not fantastic, but rather fantastic- 
marvellous. However, if one thinks the meaning of the ending is ambiguous, then the film remains purely fantastic.

The ending of Take Shelter has been debated among spectators, and there is no singular interpretation of its meaning. Contrasting reactions to the film's ending are evident online, through various blogs, message boards, and reviews. Michael Allen's review on the website 28 Days Later Analysis states, "Curtis' predictions have come true and the film shifts from covering and coping with mental illness to something a little more short sighted." 52 On the other hand, Søren Hough writes for the website Movie Fail Reviews, "It is my opinion that the finals [sic] scene of Take Shelter takes place entirely within the mind of Curtis LaForche." 53 This speaks to the film's ambiguity and complexity, and to some degree, allows it to maintain its position in the realm of the fantastic.

Todorov contends that in fantastic narratives, the spectator tends to prefer the supernatural explanation. ${ }^{54}$ In Take Shelter, there is a sense of sadness when it seems, in the second-to-last scene, that the explanation for events is Curtis' mental illness. The final scene, which by privileging Samantha's reaction seems to confirm Curtis' premonitions, offers a sense of justification, even though it also might mean that the world is about to end.

Unlike religious films that are about belief, Take Shelter is ambiguous in its meaning. Unlike many apocalyptic films, Take Shelter neither evades the apocalypse through human intervention, nor presents divine agency, nor does it convey the apocalypse in a conclusive manner. Films that fit the fantastic-marvellous, and as Todorov states, accept a supernatural explanation, are more easily classified as religious 
films. As Take Shelter maintains its position in the realm of the fantastic, it is problematic to call it a "religious film."

Despite the broad range of apocalyptic films, and the inclusive nature of the genre, Take Shelter is quite idiosyncratic. It is not a film about the apocalypse, there is no battle between good and evil, and it does not have a heroic protagonist who saves the world. It also differs from films like Melancholia in which the apocalypse is an inevitability. It is unclear what will happen when the storm in Take Shelter actually arrives. The apocalypse is one possibility for how the film will end, but the end of the world itself is not the main concern for Nichols. Some apocalyptic films challenge the spectator by indicating that there is no resolution to the situation but the earth's destruction. This does create a sense of uneasiness, but not to the same degree as Take Shelter, in which the uneasiness comes from the uncertainty about what is actually happening and what will happen.

\section{Notes}

${ }^{1}$ Genesis 6:9 NRSV.

${ }^{2}$ Anne Billson, "Enough of the Apocalypse Films!” Telegraph, 5 July 2013, http://www.telegraph.co.uk/culture/film/10160886/Enough-of-the-apocalypse-films.html.

${ }^{3}$ Kirsten Moana Thompson, Apocalyptic Dread: American Film at the Turn of the Millennium, (Albany, NY: SUNY, 2007), 2.

${ }^{4}$ Conrad Ostwalt, "Apocalyptic," in The Routledge Companion to Religion and Film, ed. John Lyden, (New York: Routledge, 2009), 375.

${ }^{5}$ Ibid.

${ }^{6}$ Ibid.

${ }^{7}$ Ibid.

${ }^{8}$ Ibid.

${ }^{9}$ Ibid, 376.

${ }^{10}$ Ibid.

${ }^{11}$ Thompson, 1. 
${ }^{12}$ Thompson, 1.

${ }^{13}$ Ibid.

${ }^{14}$ Ibid, 2.

${ }^{15}$ Ibid, 27.

${ }^{16}$ Ibid, 13.

${ }^{17}$ Robert Koehler, "Take Shelter: Jeff Nichols' Age of Anxiety," Cinema Scope, CS47, no date, http://cinema-scope.com/cinema-scope-magazine/interviews-take-shelter-jeff-nichols-age-ofanxiety/.

${ }^{18}$ Tom Huddleston, Review of Take Shelter, Time Out, 30 Sept 2011, http://www.timeout.com/london/film/take-shelter.

${ }^{19}$ Koehler, "Take Shelter: Jeff Nichols' Age of Anxiety."

${ }^{20}$ Jay Michaelson, "Religious Belief or Mental Illness?” Religion Dispatches, 10 Dec 2011, http://www.religiondispatches.org/archive/culture/5474/religious_belief_or_mental_illness/.

${ }^{21}$ Randall Balmer, "“Thy Kingdom Come': Apocalypticism in American Culture," Union

Seminary Quarterly Review 49, no.1-4 (1 Jan 1995), 19.

${ }^{22}$ Ibid, 25.

${ }^{23}$ Ibid, 27.

${ }^{24}$ David S. New, Christian Fundamentalism in America: A Cultural History, (Jefferson, NC: McFarland \& Company, 2012), 213.

${ }^{25}$ Ibid, 214.

${ }^{26}$ Ibid.

${ }^{27}$ Ibid, 174.

${ }^{28}$ Ibid.

${ }^{29}$ Ibid.

${ }^{30}$ Steven D. Greydanus, Review of The Passion of Joan of Arc, Decent Films Guide, no date, http://www.decentfilms.com/reviews/passionofjoanofarc.

${ }^{31}$ John Lopez, "Sundance Favorite and Indie Auteur Jeff Nichols's Big Influence? Steven Spielberg," Vanity Fair, 21 Jan 2011, http://www.vanityfair.com/online/oscars/2011/01/who-isindie-auteur-jeff-nicholss-big-influence-steven-spielberg.

${ }^{32}$ Craig Hubert, "Jeff Nichols's Shelter Island," Interview Magazine, no date, http://www.interviewmagazine.com/film/jeff-nichols-take-shelter\#_.

${ }^{33}$ John W. Martens, The End of the World: The Apocalyptic Imagination in Film and Television, (Winnipeg, MB: J. Gordon Shillingford, 2003), 7.

${ }^{34} \mathrm{Ibid}, 8$.

${ }^{35}$ Dereck Daschke, Review of Take Shelter, Journal of Religion \& Film 16, no.1, 2012. http://digitalcommons.unomaha.edu/jrf/vol16/iss1/13.

${ }^{36}$ Vincent Canby, Review of Close Encounters of the Third Kind, New York Times, 17 Nov 1977, http://www.nytimes.com/1977/11/17/movies/moviesspecial/17CLOS.html.

${ }^{37}$ J. Ryan Parker, “A Panic Takes Hold,” Review of Take Shelter, Patheos, 15 Feb 2012, http://www.patheos.com/blogs/poptheology/2012/02/take-shelter/.

${ }^{38}$ Alissa Wilkinson, Review of Take Shelter, Christianity Today, 30 Sept 2011, http://www.christianitytoday.com/ct/2011/septemberweb-only/takeshelter.html.

${ }^{39}$ Tzvetan Todorov, The Fantastic: A Structural Approach to a Literary Genre, (Ithaca, NY: Cornell UP, 1977), 25.

${ }^{40}$ Ibid.

${ }^{41}$ Ibid.

${ }^{42}$ Ibid, 31.

${ }^{43}$ Ibid, 33.

${ }^{44}$ Ibid.

${ }^{45}$ Ibid. 
${ }^{46}$ A.O. Scott, "A Splintering Psyche or Omens of Disaster?" Review of Take Shelter, New York Times, 29 Sept 2011, http://movies.nytimes.com/2011/09/30/movies/take-shelter-with-michaelshannon-and-jessica-chastain.html.

${ }^{47}$ Todorov, 41.

${ }^{48}$ Ibid.

${ }^{49}$ Ibid.

${ }^{50}$ Ibid, 45.

${ }^{51}$ Ibid.

${ }^{52}$ Michael Allen, “Take Shelter and A Film's True Meaning: A Movie Review," 28 Days Later Analysis, 30 Jan 2012, http://www.28dayslateranalysis.com/2012/01/take-shelter-and-films-truemeaning.html.

${ }^{53}$ Søren Hough, “Op-Ed: Understanding Take Shelter," Movie Fail Reviews, 3 July 2012, http://moviefail.com/2012/07/03/op-ed-understanding-take-shelter/.

54 Todorov, 49. 


\section{CONCLUSION}

The road to the sacred leads through the secular. -Abraham Joshua Heschel

As an intervention in the field of religion and film, this thesis has presented an approach grounded in film studies to analyze three contemporary films and the ways they engage with religion. The films examined were purposefully selected because they fall outside of popular Western cinema, and thus, the centre of focus for much religion and film scholarship. By spotlighting films from distinctive genres and national cinemas, this thesis has demonstrated the traditional and exceptional ways films engage with religious content in terms of film style, narrative, genre, character, and dichotomies such as faith versus doubt, and religion versus mental illness.

The films Silent Light, Requiem, and Take Shelter subvert the conventions of "religious" films, which tend to affirm religious belief, and which are commonly discussed in religion and film scholarship. The exceptional aspects of these three films include the rejection of an explicitly religious explanation for the events that take place, and an ambiguity that does not deny the religious, but most significantly, does not affirm it. In each of these three films, an expected religious element - resurrection, demonic possession, the end of the world - is treated in an ambiguously secular way. These films are not atheistic, but rather hesitate from providing a definitively religious reading. The secularization at work in these films is tied to their ambiguity. As religious studies scholar Bryan Stone comments, "Secularization is an ambiguous reality." ${ }^{11}$ Each of the three films examined in this thesis can be interpreted in a variety of ways.

The unique features of Requiem and Take Shelter can be understood in relation to more conventional films with similar narratives. By situating Requiem within the context 
of the exorcism film genre, and more broadly, the conventions of horror cinema, and by situating Take Shelter within the apocalyptic film genre, and in relation to prophetic narratives, the exceptional aspects of these two films are brought to light. Silent Light is also a film that defies genre classification, although it is an art film and utilizes stylistic devices associated with art cinema. Its unique features are evident in relation to Ordet, which is more of a traditional religious film, and more of a transcendental film, as expounded by Paul Schrader.

Each of the films demarcates itself from more explicitly religious filmic traditions by secularizing the typically religious aspect of the narrative. In Silent Light, there is no indication that God is responsible for the miracle of Esther's resurrection. Marianne performs the action, and does not pray for it, or invoke God, as Johannes does in Ordet. The ending of the film does not allow the spectator to witness Johan's reunion with Esther. Therefore, Johan does not have the same renewal of faith as Mikkel in Ordet, who is reunited with his wife Inger, and who believes God is responsible for Inger's resurrection. Despite the religious connotation of resurrection, Silent Light's ending is ambiguous and significantly less overtly religious than Ordet. In Requiem, neither God nor the devil is present. Whereas other exorcism films affirm belief in supernatural forces of good and evil by showing the supernatural, Requiem does not. However, the film is also not declarative that Michaela was simply mentally ill. The ending is less definitive than if her death had been included in the film, as it does not show how the exorcisms killed her. In Take Shelter, the religious aspect of apocalyptic cinema is absent. The ending hints at the supernatural but is too indeterminate to be considered religious. 
Furthermore, Curtis' prophecies are not religious in nature and do not cause him to become a religious individual.

Silent Light, Requiem, and Take Shelter are in many ways defined by their surprising endings. Each of the films ends without resolution or explanation for what has happened or what is anticipated. In Silent Light, the film ends without showing Johan and Esther's reunion, and without giving any explanation for how Esther has come back to life. In Requiem, the film ends abruptly and only reveals Michaela's fate via postscript. It does not show the series of exorcisms that it states exhausted and killed her. In Take Shelter, when it seems a degree of resolution has been reached for Curtis, the storm on the horizon in the last scene rescinds this resolution. Furthermore, the film ends without showing how the storm will affect Curtis and his family.

The expected divine agency, such as God resurrecting Esther in Silent Light, God (through the exorcist) expelling Michaela's demons in Requiem, God revealing the storm to Curtis, or averting the storm in Take Shelter, is absent from all these films. Requiem, for example, provides no conclusive evidence that God or the devil exists. Everything that happens in the film can be explained naturally, yet it does not definitively deny the religious. In Silent Light, there is no way of explaining how Esther, who was absolutely dead, is brought back to life. There is no indication that the ending is imagined or allegorical. Particularly in relation to its homage of Ordet, the resurrection is very real. Something supernatural is the cause of Esther's renewed life, but no indication is given as to what that supernatural element is. Take Shelter, near its end, seems to take a similar position as Requiem, and explain its strange events through Curtis' mental illness. However, the film foregrounds its hesitation in a more direct way than Requiem, and 
through the very last scene, renews its ambiguity toward the unexplained events. Similar to Silent Light, Take Shelter's ending, which showcases the storm from Curtis' dreams, presents something that cannot be explained naturally. The oily rain and storm on the horizon are not natural environmental occurrences. While some explain the ending as an allegory or dream, the focus on Curtis' wife and daughter and their reactions rather than Curtis' reaction indicates that this is not another of his dreams or visions. Like Silent Light, there is no suggestion that God is responsible for the storm, or for Curtis' prophetic knowledge. Rather than denying the possibility of divine agency, these films simply do not show it. In Bandy and Monda's The Hidden God, many of the films discussed suggest that God is present but in a "hidden" way. In Silent Light, Requiem, and Take Shelter, it is what is absent rather than what is present that defines their engagement with religion. None of these films are "religious" per se, but they can perhaps be considered religiously engaged films, or religiously aware.

These three films indicate the emergence of a contemporary cinema that acknowledges a religious context but engages with it in new and challenging ways. The stylistic decisions behind Requiem, for example, are particularly significant because of how they oppose the stylistic conventions of other exorcism films. This is perhaps fitting in the early $21^{\text {st }}$ century, in which society is more secular than ever before, yet the importance and influence of religion is still palpable. Even as religious belief and formal practice may continue to diminish, concerns with the spiritual, and the place of traditional religious elements in modern culture indicate that religion is far from irrelevant. What is continuing to change is the way society engages with religion, in a more complex and 
critical way, but with an openness, as Bryan Stone suggests. ${ }^{2}$ This openness does not assume or defer to the possibility of the sacred or divine, but also does not deny it.

There is much more to be explored with regard to the topic of religion and film beyond the scope of this thesis. One methodological approach could involve the study of popular cinema, as current religion and film scholarship has, but through formal film analysis, with a consideration of film theory and history. Generally, there is much more room for an examination of films that are not explicitly or definitively religious, and therefore may not have been previously considered within religion and film scholarship. In particular, art cinema is an underdeveloped area of work on religion and film. Another approach would be to contemplate Schrader's transcendental style as it may be applied and adapted to contemporary films beyond Silent Light, and the careers of auteurs more recent than Ozu, Dreyer, and Bresson.

Alternatively, one could study national cinemas, and consider films from a particular country in the context of its religious culture. Chapter Three touches on this, in relating Take Shelter to American apocalypticism, but this topic could be a thesis in and of itself. One could also consider the changes in how religion is conveyed in films over different time periods. As stated above, contemporary films may engage with religion in new and challenging ways because society engages with religion in more complex ways. A larger study of contemporary films would better indicate possible trends or developments. Additionally, such a study could consider related or similar films beyond Ordet and Silent Light.

Religion and film is still a budding area of study and there is much room for growth on both the religious studies and film studies sides of the field. At the intersection 
of these two disciplines lie new considerations of how, as Abraham Joshua Heschel's quote suggests, the sacred and secular are intertwined.

\section{Notes}

${ }^{1}$ Bryan Stone, "The Sanctification of Fear: Images of the Religious in Horror Films," Journal of Religion \& Film 5, No. 2 (Oct 2001), http://www.unomaha.edu/jrf/sanctifi.htm.

${ }^{2}$ Ibid. 


\section{BIBLIOGRAPHY}

Aichele, George and Richard G. Walsh. Screening Scripture: Intertextual Connections Between Scripture and Film. Harrisburg, PA: Trinity International, 2002.

Allen, Michael. “Take Shelter and A Film's True Meaning: A Movie Review.” Review of Take Shelter. 28 Days Later Analysis, 30 Jan 2012.

http://www.28dayslateranalysis.com/2012/01/take-shelter-and-films-truemeaning.html.

Badt, Karin Luisa. "Silent Light or Absolute Miracle: An Interview with Carlos Reygadas at Cannes 2007." Bright Lights Film Journal, Issue 57 (August 2007).

http://brightlightsfilm.com/57/reygadasiv.php\#.UbpEoBalafQ.

Balmer, Randall. "“Thy Kingdom Come': Apocalypticism in American Culture." Union Seminary Quarterly Review 49, no.1-4 (1 Jan 1995): 17-33. ATLA Religion Database with ATLASerials, EBSCOhost.

Bandy, Mary Lea and Antonia Monda, editors. The Hidden God: Film and Faith. New York: Museum of Modern Art, 2003.

Bankersen, Leo. "From the Everyday to Stasis." Film Krant, Feb 2009. http://www.filmkrant.nl/slowcriticism_2009/6804.

Billson, Anne. "Enough of the Apocalypse Films!” Telegraph, 5 July 2013. http://www.telegraph.co.uk/culture/film/10160886/Enough-of-the-apocalypsefilms.html.

Bird, Michael. "Film as Hierophany." In Religion in Film, edited by John R. May and Michael Bird, 3-22. Knoxville: University of Tennessee, 1982.

Bordwell, David. Ozu and the Poetics of Cinema. Princeton: Princeton UP, 1988.

Bradshaw, Peter. Review of Requiem. Guardian, 17 Nov 2006. http://www.theguardian.com/film/2006/nov/17/worldcinema.drama.

Burke, Daniel. "They're Baaack! What's behind the return of the exorcist." U.S. Catholic, June 2011 Issue. http://www.uscatholic.org/church/2011/05/theyrebaaack-whats-behind-return-exorcist.

Cabrero, Daniel G. “An Interview with Requiem Director Hans-Christian Schmid.” Vert!go Magazine Issue 5 (Nov 2006).

http://www.closeupfilmcentre.com/vertigo_magazine/issue-5-november2006/requiem/ 
Canby, Vincent. Review of Close Encounters of the Third Kind. New York Times, 17 Nov 1977. http://www.nytimes.com/1977/11/17/movies/moviesspecial/17CLOS.html.

Castillo, José. “Carlos Reygadas.” Includes interview with Carlos Reygadas. Bomb 111 (Spring 2010). http://bombsite.com/issues/111/articles/3452.

Catsoulis, Jeannette. "A Mind in Torment Faces a Terrible Decline.” Review of Requiem. New York Times, 20 Oct 2006. http://movies.nytimes.com/2006/10/20/movies/20requ.html?_r=0.

Close Encounters of the Third Kind. Directed by Steven Spielberg. 1977. USA. Sony Pictures Home Entertainment, 2007. DVD.

Cockrell, Eddie. Review of Requiem. Variety, 27 Feb 2006. _http://variety.com/2006/film/reviews/requiem-3-1200518310/.

Cowan, Douglas. "Horror and the Demonic." In The Routledge Companion to Religion and Film, edited by John Lyden, 403-419. New York: Routledge, 2009.

Daschke, Dereck. Review of Take Shelter. Journal of Religion \& Film 16, no.1 (25 May 2012). http://digitalcommons.unomaha.edu/jrf/vol16/iss1/13.

De Luca, Tiago. "Carnal Spirituality: The Films of Carlos Reygadas." Senses of Cinema 55 (July 2010). http://sensesofcinema.com/2010/feature-articles/carnalspirituality-the-films-of-carlos-reygadas- $2 /$.

Derrickson, Scott and Paul Harris Boardman. "Genesis of the Story." The Exorcism of Emily Rose. DVD. Sony Pictures Home Entertainment, 2005.

Diamond, Stephen. Anger, Madness, and the Daimonic: The Psychological Genesis of Violence, Evil, and Creativity. Albany, NY: State University of New York, 1996.

The Exorcism of Emily Rose. Directed by Scott Derrickson. 2005. USA. Sony Pictures Home Entertainment, 2005. DVD.

The Exorcist. Directed by William Friedkin. 1973. USA. Warner Home Video, 2001. DVD.

Fleming, Michael and Roger Manvell. Images of Madness: the Portrayal of Insanity in the Feature Film. N.J.: Fairleigh Dickinson UP, 1985.

Geivett, R. Douglas and James S. Spiegel. Faith, Film and Philosophy: Big Ideas on the Big Screen. Downers Grove, IL: IVP Academic, 2007. 
Gilmour, David. Review of The Exorcism of Emily Rose. Globe and Mail, 9 Sept 2005. http://www.theglobeandmail.com/arts/the-exorcism-of-emilyrose/article1123623/.

Greydanus, Steven D. Review of The Passion of Joan of Arc. Decent Films Guide, no date. http://www.decentfilms.com/reviews/passionofjoanofarc.

Harper, Stephen. Madness, Power and the Media: Class, Gender and Race in Popular Representations of Mental Distress. Houndmills, Basingstoke, Hampshire: Palgrave Macmillan, 2009.

Hough, Søren. “Op-Ed: Understanding Take Shelter.” Movie Fail Reviews, 3 July 2012. http://moviefail.com/2012/07/03/op-ed-understanding-take-shelter/.

Hubert, Craig. “Jeff Nichols’s Shelter Island.” Interview Magazine, 14 Sept 2011. http://www.interviewmagazine.com/film/jeff-nichols-take-shelter\#_.

Huddleston, Tom. Review of Take Shelter. Time Out, 30 Sept 2011. http://www.timeout.com/london/film/take-shelter.

Jenkins, David. “Carlos Reygadas: Interview.” Time Out, 2007. http://www.timeout.com/london/film/carlos-reygadas-interview-1.

Journal of Religion and Film website. Hosted by the University of Nebraska Omaha. http://digitalcommons.unomaha.edu/jrf/.

Koehler, Robert. “Take Shelter: Jeff Nichols' Age of Anxiety.” Includes interview with Jeff Nichols. Cinema Scope CS47, no date. http://cinema-scope.com/cinemascope-magazine/interviews-take-shelter-jeff-nichols-age-of-anxiety/.

LaSalle, Mick. "Reality's a Slippery Thing When the Devil's Doing the Talking." Review of The Exorcism of Emily Rose. San Francisco Chronicle, 9 Sept 2005. http://www.sfgate.com/movies/article/Reality-s-a-slippery-thing-when-the-devils-doing-2578024.php.

Lopez, John. "Sundance Favorite and Indie Auteur Jeff Nichols's Big Influence? Steven Spielberg." Includes interview with Jeff Nichols. Vanity Fair, 31 Jan 2011. http://www.vanityfair.com/online/oscars/2011/01/who-is-indie-auteur-jeffnicholss-big-influence-steven-spielberg.

Lyden, John C. Film as Religion: Myths, Morals, and Rituals. New York: New York UP, 2003.

---, editor. The Routledge Companion to Religion and Film. New York: Routledge, 2009. 
Marsh, Clive and Gaye Ortiz, editors. Explorations in Theology and Film: Movies and Meaning. Oxford: Blackwell, 1997.

Marshall, Lee. Review of Requiem. Screen International, 20 Feb 2006. http://www.screendaily.com/requiem/4026250.article.

Martens, John W. The End of the World: The Apocalyptic Imagination in Film and Television. Winnipeg, MB: J. Gordon Shillingford, 2003.

Martin, Joel W. and Conrad E. Ostwalt, editors. Screening the Sacred: Religion, Myth, and Ideology in Popular American Film. Boulder: Westview Press, 1995.

May, John R., editor. Image \& Likeness: Religious Visions in American Film Classics. New York: Paulist Press, 1992.

McCarthy, Susan. "What Happens at Exorcism School?” Guardian, 21 Dec 2010. http://www.guardian.co.uk/commentisfree/belief/2010/dec/21/exorcismconference-devils-demons.

Michaelson, Jay. "Religious Belief or Mental Illness?” Religion Dispatches 10 Dec 2011. http://www.religiondispatches.org/archive/culture/5474/religious_belief_or_ment al_illness/.

Miles, Margaret R. Seeing and Believing: Religion and Values in the Movies. Boston: Beacon, 1996.

Mitchell, Jolyon P. and S. Brent Plate, editors. The Religion and Film Reader. New York: Routledge, 2007.

Monda, Antonio. "Close Encounters of the Third Kind." In The Hidden God: Film and Faith, edited by Mary Lea Bandy and Antonio Monda, 150-153. New York: The Museum of Modern Art, 2003.

Nayar, Sheila J. The Sacred and the Cinema: Reconfiguring the "Genuinely" Religious Film. New York: Continuum, 2012.

New, David S. Christian Fundamentalism in America: A Cultural History. Jefferson, NC: McFarland \& Company, 2012.

Niessen, Niels. "Miraculous Realism: Spinoza, Deleuze, and Carlos Reygadas's Stellet Licht." Discourse 33, no.1 (2011): 27-54. doi:10.1353/dis.2011.0003.

Ordet. Directed by Carl Theodor Dreyer. 1955. Denmark. Criterion Collection, 2004. DVD. 
Ostwalt, Conrad. "Apocalyptic." In The Routledge Companion to Religion and Film, edited by John Lyden, 368-383. New York: Routledge, 2009.

Parker, J. Ryan. “A Panic Takes Hold.” Review of Take Shelter. Patheos, 15 Feb 2012. http://www.patheos.com/blogs/poptheology/2012/02/take-shelter/.

Peña, Richard. "Transformations: New Spins on Spiritual Crisis and Growing Pains." Review of Silent Light. Film Comment 43, no.4 (July 2007): 66-67. Art \& Architecture Complete, EBSCOhost.

Plate, S. Brent. Religion and Film: Cinema and the Re-Creation of the World. New York: Wallflower, 2008.

Quicke, Andrew. "Phenomenology in Film: An Examination of a Religious Approach to Film Theory by Henri Agel and Amédée Ayfre." Journal of Media \& Religion 4, no. 4 (2005). doi: 10.1207/s15328415jmr0404_2.

Reinhartz, Adele. Scripture on the Silver Screen. Louisville, KY: Westminster John Knox Press, 2003.

Requiem. Directed by Hans-Christian Schmid. 2006. Germany. Mongrel, 2006. DVD.

Schrader, Paul. Transcendental Style in Film: Ozu, Bresson, Dreyer. Berkeley: University of California Press, 1972.

Scott, A.O. "A Splintering Psyche or Omens of Disaster?” Review of Take Shelter. New York Times, 29 Sept 2011. http://movies.nytimes.com/2011/09/30/movies/takeshelter-with-michael-shannon-and-jessica-chastain.html.

Silent Light. Directed by Carlos Reygadas. 2007. Mexico. Seville Pictures, 2008. DVD.

Stone, Bryan. "The Sanctification of Fear: Images of the Religious in Horror Films." Journal of Religion \& Film 5, no. 2 (October 2001). http://www.unomaha.edu/jrf/sanctifi.htm.

Take Shelter. Directed by Jeff Nichols. 2011. USA. Sony Pictures Classics, 2012. DVD.

Teodoro, José. "Silent Witness: An Interview with Carlos Reygadas," Cineaste 34, no. 2 (2009). http://www.cineaste.com/articles/emsilent-lightem-an-interview-withcarlos-reygadas.

Thompson, Kirsten Moana. Apocalyptic Dread: American Film at the Turn of the Millennium. Albany, NY: SUNY, 2007.

Todorov, Tzvetan. The Fantastic: A Structural Approach to a Literary Genre. Ithaca, NY: Cornell UP, 1977. 
Wilkinson, Alissa. Review of Take Shelter. Christianity Today, 30 Sept 2011. http://www.christianitytoday.com/ct/2011/septemberweb-only/takeshelter.html.

Zimmerman, Jacqueline. People like Ourselves: Portrayals of Mental Illness in the Movies. Lanham, MD: Scarecrow, 2003. 